\title{
Integrating Geotechnical Investigation with Hydrological Modeling for Mitigation of Expansive Soil Hazards in Tabuk City, Saudi Arabia
}

\author{
Abd-Alrahman Embaby1, Ayman Abu Halawa², Medhat Ramadan' \\ ${ }^{1}$ Geology Department, Faculty of Science, Damietta University, Damietta, Egypt \\ ${ }^{2}$ Nuclear Material Authority, Cairo, Egypt \\ Email:embaby@du.edu.eg, halawa1970@yahoo.com
}

How to cite this paper: Embaby, A.A., Halawa, A.A. and Ramadan, M. (2017) Integrating Geotechnical Investigation with Hydrological Modeling for Mitigation of Expansive Soil Hazards in Tabuk City, Saudi Arabia. Open Journal of Modern Hydro$\log$, 7, 11-37.

http://dx.doi.org/10.4236/ojmh.2017.71002

Received: December 10, 2016

Accepted: January 23, 2017

Published: January 26, 2017

Copyright (c) 2017 by authors and Scientific Research Publishing Inc. This work is licensed under the Creative Commons Attribution International License (CC BY 4.0).

http://creativecommons.org/licenses/by/4.0/

(c) $\underset{\mathrm{EY}}{\text { (i) Open Access }}$

\begin{abstract}
Due to global climatic changes, flash floods are followed as a yearly disaster with high magnitude of influence. During the years 1981, 1988, 2010, 2012 and in January 2013, Tabuk city, northwest of Saudi Arabia suffered huge flash floods. These are major factors affecting on the swelling behavior of expansive Tabuk shale. The examined geotechnical properties of the surface and subsurface lithology of the sedimentary deposits distinguished Tabuk city into three zones. The expansive zone is spread in the middle and the non-expansive zones are distributed in the east and west of the city. The Watershed Modeling System (WMS) and Hydrologic Engineering Center (HEC-1) models were used to delineate and identify the drainage system and basin morphometry, where flash floods and accumulation of water might take place. Integration between geotechnical distribution maps of the expansion soil and surface hydrological data in terms of runoff maps was done. It has been identified the whereabouts the soils which have expansion characteristics and areas prone to flooding and surface runoff. They are helpful in defining the hazard zones map. Based on this map, it can be avoided constructions on the risk neighborhoods such as Al Qadsiyah, Al Maseif, Arrwdah, Al Nakhil and Al Rajhi. Also, it can suggest that the western side of Tabuk city is suitable for future urban extension. These results will help planners and citizens to create alternative development scenarios and determine their impact on the future urbanization patterns. Moreover, the direction of surface runoff flow or storm water discharge should be away from the expansion soil areas. Therefore, constructing dams on the outlet of the high-risk basins, south of Tabuk city is an important solution to control flash flood events, as well as increase groundwater recharge.
\end{abstract}

\section{Keywords}

Expansion Soil Hazards, Flash Floods, Geotechnical Investigation, Saudi Arabia, 
Tabuk City, Watershed Modeling System

\section{Introduction}

Soils and soft rock that tends to swell or shrink due to changes in moisture content are commonly known as expansive soils [1]. Damages to infrastructure caused by expansi- ve soil movement have been widely reported in many countries such as Australia, China, United States, India and South Arica [2]. In America, the economic loss of the expansive soil question approximately amounts to above $\$ 15$ billion every year [3] [4] [5] more than twice the damage from natural disasters.

One of the major geotechnical problems in Kingdom of Saudi Arabia (KSA), as has recently been noticed, is the swelling potential of the soils upon change in moisture content. Tabuk city, northwest KSA, is underlain by a shale; it is the primary source of expansive soils [6] [7] [8] [9] [10]. The problem in Tabuk is a terrifying for the administrative, municipality officials and legal authorities; luxury villas, modern built, commercial buildings, schools, hospital, mosques and roads are subjected to upheaval forces. It is resulted in serious cracks, tilting, twisting and sticking doors and windows. Damages seen in some districts are estimated in the hundreds of millions US dollars [11] [12] [13]. Conducted comprehensive studies covering greater parts of the Tabukcity are included in [6] [10] [12] [14] [15] [16].

The hazard posed by expansive soils is greatest in regions with pronounced wet and dry seasons [17]. Therefore, building and infrastructure built in arid to semi-arid regions will be predisposed to expansive soil problems when compared with humid regions that maintain a rather uniform soil moisture condition throughout the year [18]. In years of extreme temperatures or rainfall, the damage is the most severe [19]. Factors that control the behavior of expansive soils have been thoroughly investigated by many researchers [1] [20] [21] [22]. The primary factor is a change in water content. Pronounced changes in water content in soils seasonally occur in many areas of the world. The potential change in water content is generally attributed to the environmental conditions which influence volume change of soil is seasonal moisture variations due to rainfall, runoff and groundwater table.

Water is introduced to the sub-soil through infiltration of rainfall and runoff, rise in the groundwater level, and human activities (leaking from subsurface utilities i.e., water or sewage systems) could adversely affect ambient moisture conditions [23] [24]. Surface drainage leads to moisture accumulation or ponding, which can provide a source of moisture for expansive soil by infiltration.

Tabuk city is hardship surface water scarcity compensated by flash flooding, which has been affecting the entire city for many years during the winter season. The catchment experienced major floods during the years 1981, 1988, 2010, 2012 in January 2013, causing unfortunately the death of many people and serious damage to residential buildings [25] [26]. Hydrological processes must play a dominant role in the swelling of the soil and rocks. Surface hydrology deals with movement of water along the watershed because of precipitation. Drainage basin morphometry plays a significant role in delineating the 
areas prone to runoff or flooding [27]. Poor surface drainage is a frequent problem associated with constructions on expansive soils. It leads to water accumulation or ponding, which can provide a source of moisture for expansive soil by infiltration. The extent of the infiltration is a function of the transverse and longitudinal gradients in the drainage tributaries, lag time of runoff, volume and peak discharge of runoff and the hydrologic soil groups.

The main objective of the current study is to investigate the runoff hazards on the expanded shale of Tabuk residential neighborhoods and to identify basin tributaries; surface runoff, flash floods location, and depressions allow accumulation or standing water, which activates the expansive shale in a localized manner leading to differential heaving of expansive soil. In addition, it will be carried an integration of geotechnical investigation and surface hydrology to construct a hazard expansive soil map of Tabuk city. It is helpful in determining the suitable future extension and development of urban areas.

\section{Location of Study Area}

Tabukcity lies in the northwestern part of KSA, between latitudes $28^{\circ} 20^{\prime} \mathrm{N}$ and $28^{\circ} 28^{\prime} \mathrm{N}$ and longitudes $36^{\circ} 26^{\prime} \mathrm{E}$ and $36^{\circ} 36^{\prime} \mathrm{E}$. It is situated on an alluvial plateau with an elevation of about $760 \mathrm{~m}$ [28]. Tabuk area is almost flat; it gently slopes downward to the north and northeast with gradually moderate relief. The plateau is frequently cut with several wadis, which drain northwards for some $20 \mathrm{~km}$ to the Qa'a Sharawa dry lakebed (Figure 1). This area has the lowest relief and forms an internal drainage for the wadis.

\section{Methodology and Technique}

\subsection{Geotechnical Properties}

The soil samples (disturbed and undisturbed) were collected from the drilled 72 boreholes to depth varied from $10 \mathrm{~m}$ to $25 \mathrm{~m}$ distributed in the Tabuk city (Figure 1). Laboratory tests are carried out to attest the potential expansiveness of the soils by grain size distribution, soil moisture content, Atterberg limits, and swell tests. All of these tests were performed in conformity with the American Standards, ASTM [29].

\subsection{Hydrological Methodology}

The used rainfall data is collected from the Hydrology Division of the Ministry of Water and Electricity [30]. The available rainfall records cover a period of 49 years (1965 to 2004). HyFrAn PLUS (Hydrological Frequency Analysis) program [31] had been used for the available rainfall data to obtain the corresponding rainfall depth values of the probabilities distribution (Gumbel, General Extreme value GEV, Pearson Type III and Log-Pearson Type III) for different return periods. The Chi-square test comparing computed values with observed values was carried out to identify the best-fit method.

Delineating drainage networks is essential to predict flow of surface water runoff, and consequently the flash flood hazards zones [32] [33]. Basin delineation was condu- cted using the Shuttle Radar Topography Mission (SRTM v.3, 1 arc) 30-m digital elevation model "DEM" (Projected Coordinate System: WGS_1984_UTM_Zone_37 N) in the Watershed Modeling System (WMS, v.10). WMS and Global Mapper (v.17) were used to 


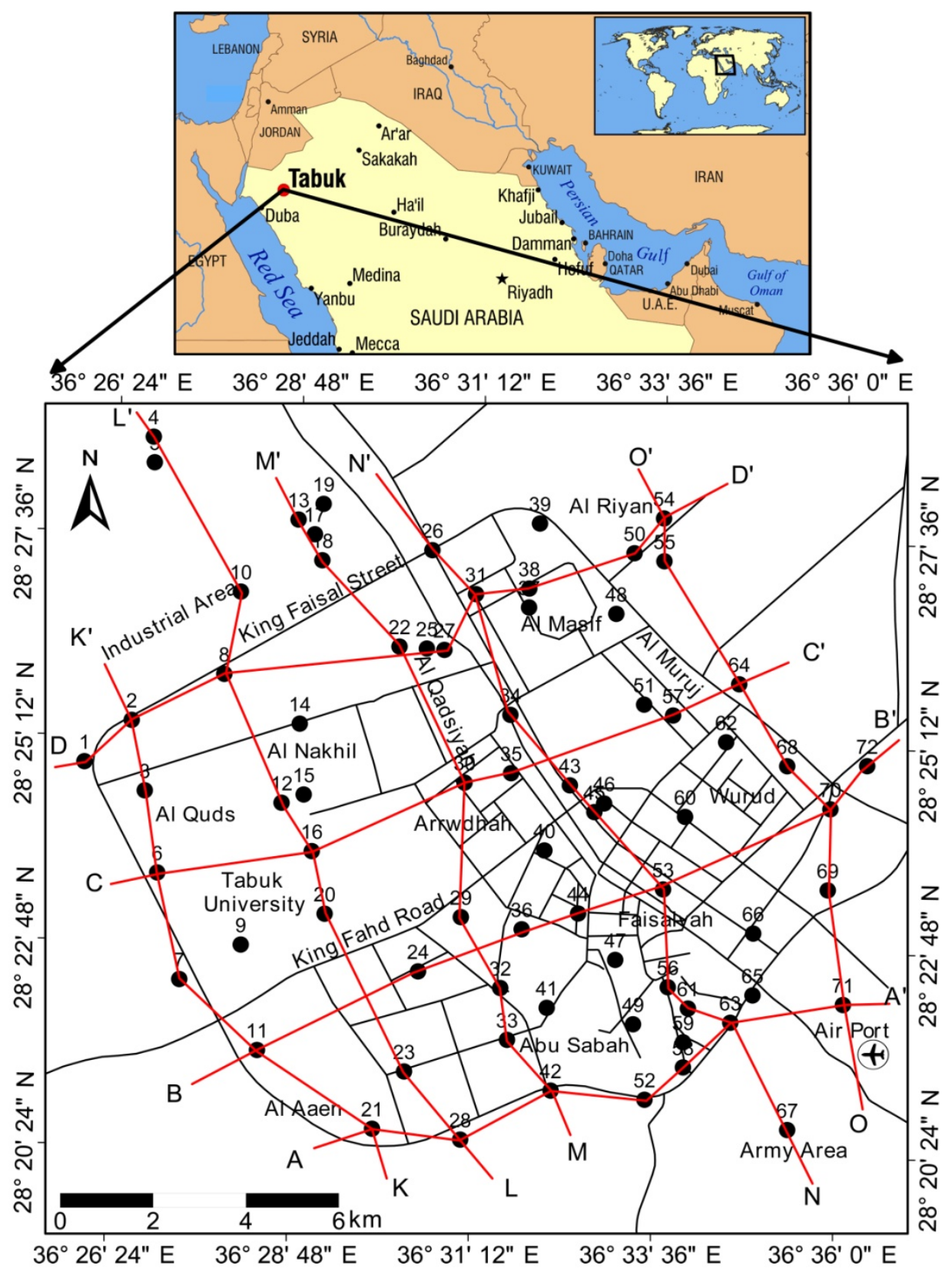

Figure 1. Location map showing distribution of drilled boreholes and cross sections, Tabuk City, KSA.

provide most of the morphometric parameters of the studied basins and their stream attributes [34].

The time of concentration constitutes an important factor in flood assessment studies, since it is the time required by runoff to travel from the most distant point to the basin's outlet point and lag time as the time from the center of mass of excess rainfall to the hydrograph peak [35]. For ungagged watersheds, the Soil Conservation Service (SCS) suggests that the UH lag time $\left(t_{\mathrm{L}}\right)$ may be estimated as 0.6 times the $t_{\mathrm{c}}\left(t_{\mathrm{L}}=0.6 t_{\mathrm{c}}\right)$.

A number of detailed hydrologic models have been developed to estimate the peak discharge and runoff hydrograph for a given rainfall distribution, such as the Hydrologic Engineering Center model (HEC-1), the SCS's Technical Release-20 model (TR- 
20), the SCS's Technical Release-55 model (TR-55). Sonbol [36] used HEC-1 with SCS Unit Hydrograph option to simulate peak discharges in Sinai, Egypt and concluded that the model reasonably predicted observed peak flow. The SCS method is suited for humid, semi-arid, and arid conditions [37]. The SCS method has been successfully applied to several ephemeral watersheds in arid environments similar to Saudi Arabia [38] [39] [40] [41] [42]. HEC-1 demonstrated acceptable performance in rainfall runoff modeling for different case studies in arid regions [43] [44] [45].

In the present study, the selected computer Rainfall-Runoff model was the Hydrologic Engineering Center (HEC-1) [32] under the Watershed Modeling System (WMS v. 10) software as it was successfully applied for hydrologic modeling of watercourses and flash floods of the daring system that flow into Tabuk city.

The peak flood discharge and volume of runoff of eight drainage basins were estimated by applying the Soil Conservation Services (SCS) method using the Hydrologic Engineering Center (HEC-1) model under WMS software program. The HEC-1 was run for 7 return periods $(2,3,5,10,20,50$ and 100 years) using the soil conservation service curve number (SCS CN) method to estimate the infiltration losses with an average antecedent moisture condition (AMC II) [37]. The SCS CN is a function of the hydrologic soil group, land use, land cover and antecedent moisture conditions [46]. Based on the geological, soil, land use and land cover characteristics, the weighed curve number $(\mathrm{CN})$ is 80 for the study area catchments.

\section{Results}

\subsection{Geological and Geotechnical Setting}

Geology of the study area was based on the geology of Tabuk Quadrangle mapped (GM-137 Sheet No. 28B) by Janjou [47] (Figure 2), field investigation and description and analyses of the drilling boreholes samples; in addition to the general geology and subsurface hydrology [48]-[56].

\subsubsection{Surface Geology}

Tabuk area is located within the sedimentary cover in the northwestern part of the Arabian Peninsula Shelf. The outcrop rock units in the Tabuk city belong to Paleozoic and Quaternary sediments (Figure 2).

Qasim and Sarah Formations represent the exposed Paleozoic sediments in Tabuk city, where it outcrops in several hills within the town limits (Figure 3). Qasim and Sarah Formations are belonging to Tayma and Tabuk groups, respectively [47]. It composed of a thick sequence of shale, siltstone, and sandstone units that belong to marine and continental facies.

It rests conformably but with a sharp contact on the sandstones of the Saq Formation. Age of Qasim Formation is Early to Late Ordovician. Its maximum thickness is about $1070 \mathrm{~m}$ but diminishes gradually in the southeast direction. The Formation is subdivided into four members, from bottom to top: Hanadir, Kahfah, Ra'an and Quwarah. In Tabuk city, Ra'an and Quwarah members are present. Ra'an Member consists of gray and dark-red, finely laminated silty clay to greenish gypsiferous clay (Figure 2 and Figure 3(a)). Quwarah Member is overlies Ra'an member. It is late Ordovician age 

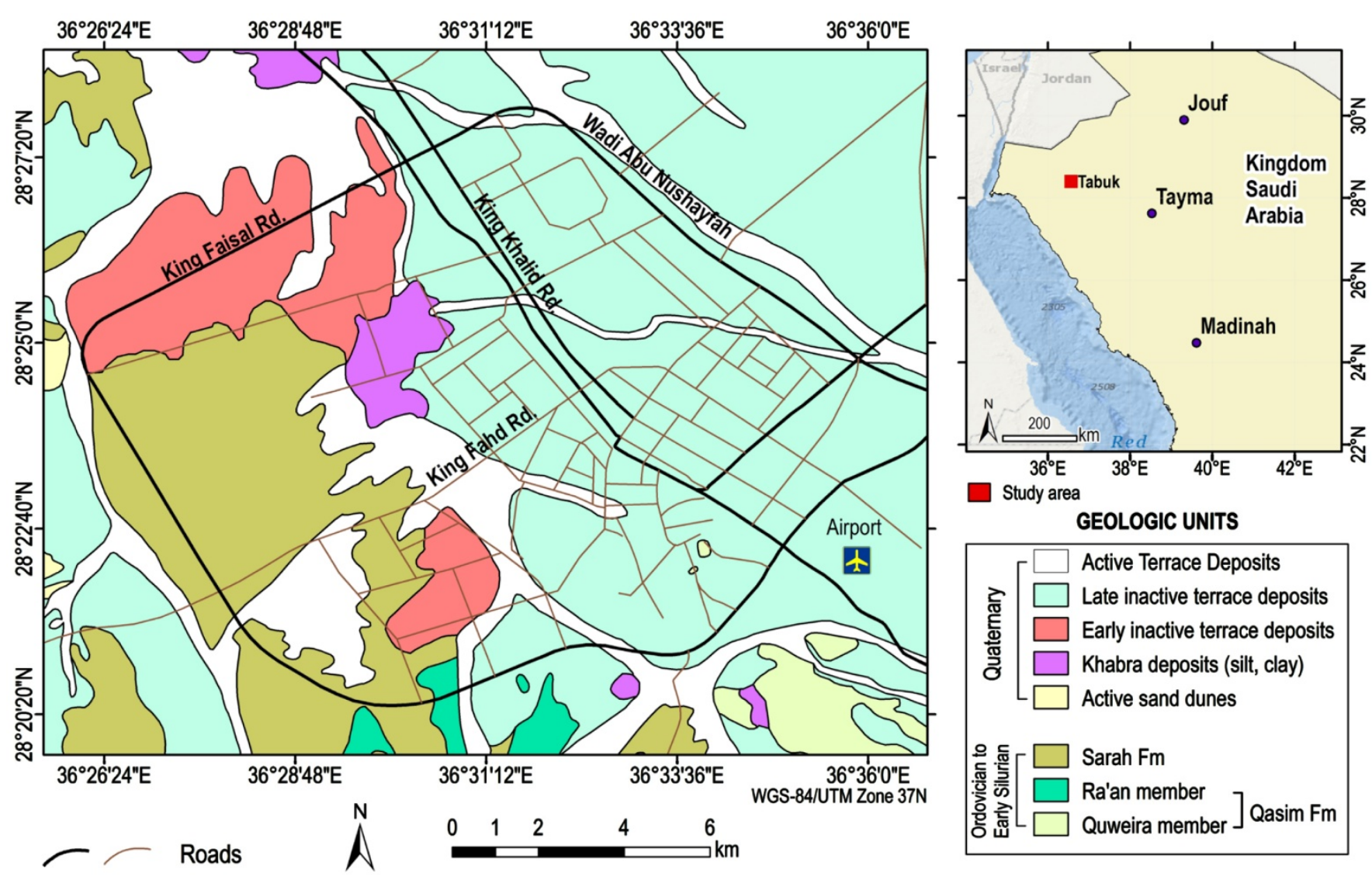

Figure 2. General geological map of Tabukcity (Modified from Janjou [47]).

[57]. Quwarah Member consists of medium to fine-grained micaceous sandstone and silty clay (Figure 2).

Sarah Formation is belonging to Tabuk Group. It is overlies Qasim Formation of Tayma Group. The age of Sarah Formation is of late Ordovician to early Silurian. Sarah Formation consists of medium to coarse-grained sandstone (Figure 2 and Figure 3(b)).

Quaternary sedimentary deposits overly Paleozoic sedimentary rocks, covered most of the study area (Figure 2). It represented by alluvial deposits (active and inactive terraces), khabra and sabkhah deposits (Figure 3(c) \& Figure 3(d)). They consist mainly of silt, clay and blown sand with variable proportions of gravel and rock fragments of basement complex and vesicular basalt (scoria), its thickness ranges from $0.5 \mathrm{~m}$ to $6 \mathrm{~m}$.

\subsubsection{Subsurface Lithology}

Through the nine lithological cross sections (Figure 1 \& Figure 4), it can be divide Tabuk city according to the subsurface lithology into three zones; these are western, central, and eastern zones.

The western zone consists of yellowish to brownish color, very fine to medium grain size, moderately sorted sandstone rock. It is found from surface to the extending depth of the borings (Figure 4). It is interbedded with thin lamination of shale. In some location, sandstone overlies by thin sandy clay, clayey sand or sand blown layers, ranges in thickness from $0.5 \mathrm{~m}$ to $1 \mathrm{~m}$. Sandstone represents the subsurface layers of the Al Aaen, Tabuk University, Al Quds Districts. 

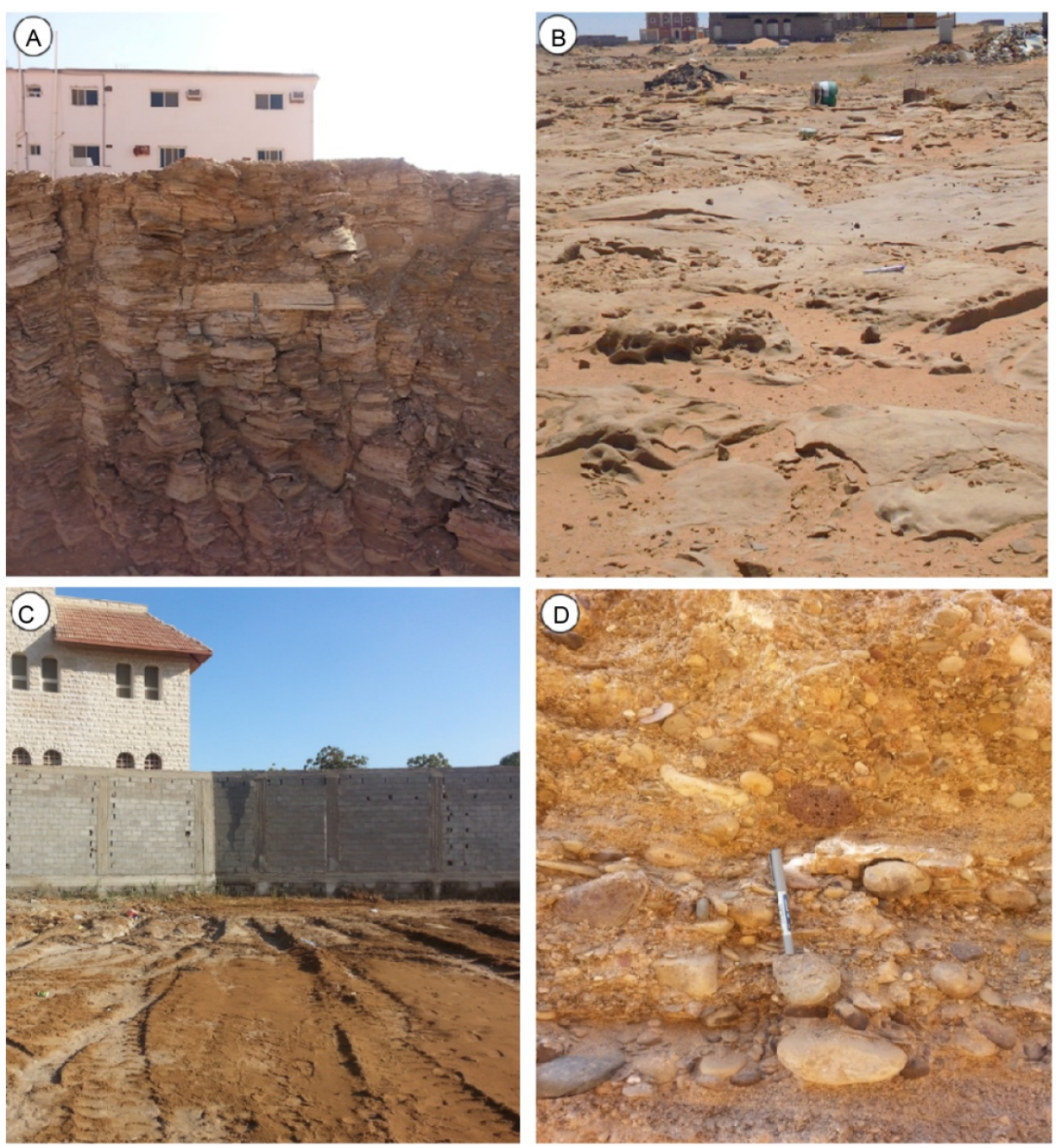

Figure 3. Exposed Tabuk rocks and sedimentary deposits: (A) shale, (B) sandstone, (C) sabkha and (D) alluvial terraces, building built direct up on it, Tabuk, KSA.

The central zone of Tabuk city consists of green to brownish silt shale layers often abundantly micaceous, oriented and laminated, flaky, interbedded with thin lamination of sandstone and lenses of gypsum. The depths of the layers range from $0 \mathrm{~m}$ to $20 \mathrm{~m}$ (Figure 4). Lateral and vertical extend of shale layers increase towards the north. Shale founds on the surface and some localities overlies by clayey sand, calcareous clayey sand, sandy clay and/or calcareous clayey sand with rock fragments layers, with thickness range from 0.5 - $3 \mathrm{~m}$ (Figure 4). Shale represents the subsurface layer of the center districts of Tabuk city such as Al Qadsiyah, Arrwdah, Al Masief, El Nakil, Annahdhah, and buildings are constructed directly on shale layers (Figure 3(a)) which represent the expansive soils.

While the eastern zone of Tabuk city consists of clayey sand with gravel and rock fragments (alluvial terraces) and sandy clay layers. These layers are occasionally thicknesses calcareous interbedded with thin lamination of gypsum or gravel coating by thin layer of gypsum. Their depths range from $0 \mathrm{~m}$ to $15 \mathrm{~m}$ (Figure 4). It represents the subsurface layers of the most of districts east King Khaled Street such as Al Muruj, $\mathrm{Al}$ Wurud, Al Faisalyah, Ulaya, Sultanah, Asulimaniyah, Al Mahrajan, etc. 


\subsubsection{Geotechnical Properties of Expansive Soil}

Shale is the primary source of expansive soils in Tabuk due to the presence of clay minerals (smectite and illite) that are derived from shale [6] [7] [8] [9] [58]. Sabtan [10] found that, the degree of soil expansion in Tabuk ranges from low to very high.

From the geotechnical properties and mineralogical composition of Tabuk shale, it had low to mediums welling potential, according to the criteria proposed by [1] [59] [60] [61] [62]. The mineralogical composition of clay constituents of the shale, investigated using X-ray diffraction analysis reveals that the predominant clay minerals are

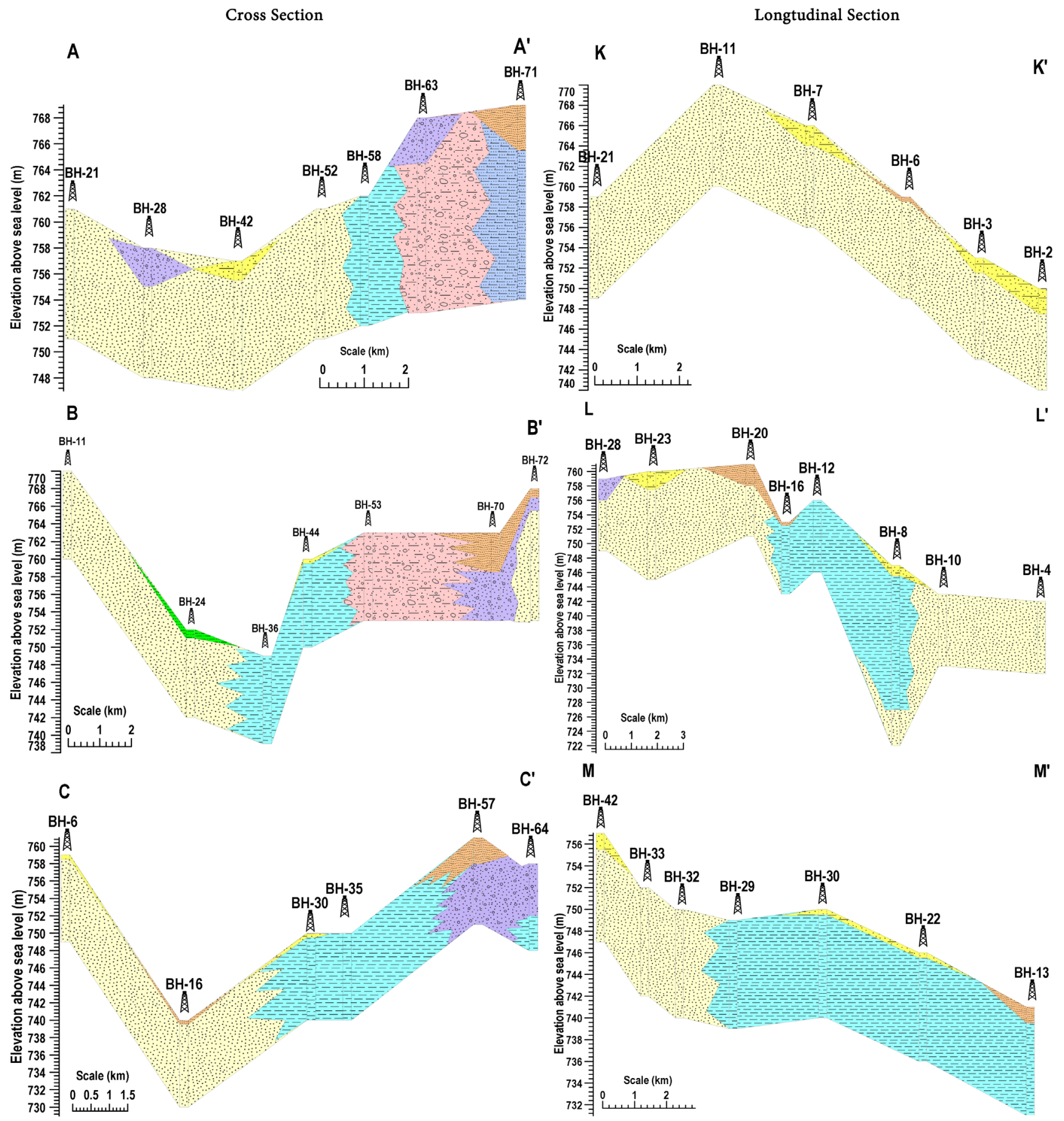




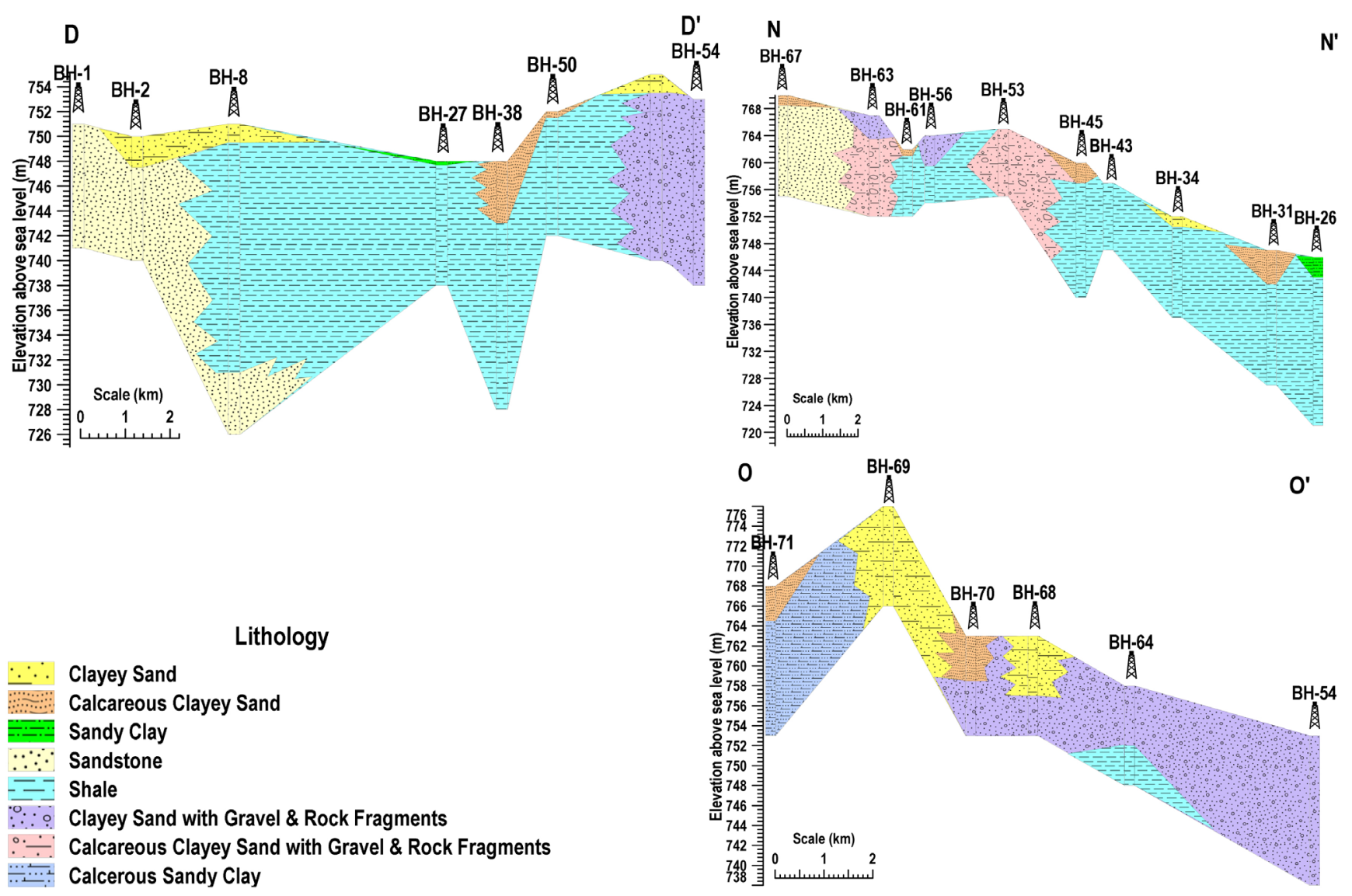

Figure 4. Lithological cross-sections (A-A', B-B', C-C', D-D', K-K', L-L', M-M', N-N', O-O') of Tabuk city, Tabuk, KSA.

kaolinite with minor amounts of illite [62]. The expansive lattice-type clay mineral (i.e., montmorillonite) cannot be traced in the shale. Both kaolinite and illite minerals are known for being low to moderately expansive materials.

The geotechnical properties of the surface and subsurface lithology of the sedimentary deposits and/orrocks showed that, shale layers of (Ra'an member) have expansive characteristic, whatever sandstone (Sarah Formation) and clayey sand with gravel and rock fragments (Quaternary alluvial deposits) layers are non-expansive.

\subsubsection{Distribution of Expansive Soil}

Based on the field geology, subsurface lithology, and geotechnical properties of the investigated soil samples of Tabuk city, it can be distinguished Tabuk city into three zones (Figure 5) from geotechnical view as follow.

The expansive zone is spread in the middle of the city, composed of shale. This zone is narrow in the south and become wider in the north of the city. The neighborhoods of Arrwadah, Al Farabi, Annahdhah, Al Nakhil, Rahil, Al Rajhi, Al Qadsiyah and Al Masef are situated in the expansive zone and suffered significant damage to constructions.

The non-expansive zones are distributed in the east and west of Tabuk city, represented by alluvial deposits (silt, clay and blown sand with variable proportions of gravel and rockfragments) and sandstone eastwards and westwards zones. The neighborhoods of the east, west, and southern parts of Tabuk city are underlain by non-expansive deposits and/or rocks and did not show problems to constructions. 


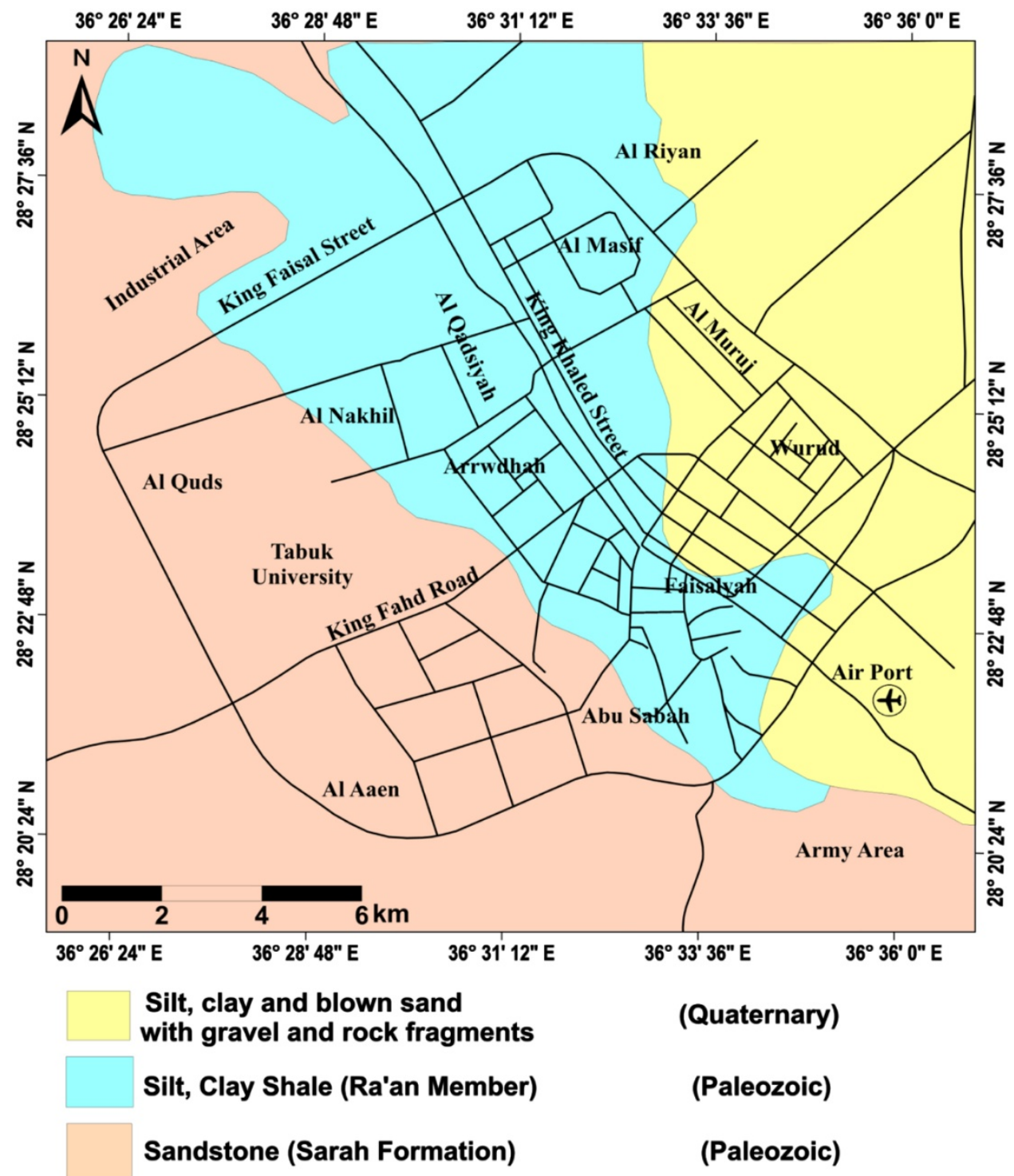

Figure 5. Distribution of the expansive and non-expansive soils in Tabuk city, KSA.

\subsection{Surface Hydrology Analysis}

\subsubsection{Rainfall Analysis}

Climate conditions play an important role in defining the hydraulic response of the watersheds existing in Tabuk city and it's environ. The most important factor affecting the hydraulic behavior of the wadi basins is rainfall. Its duration, intensity, distribution, and return periods are major influences.

In Tabuk city, the amount of rainfall is irregular through the years and through the months (Table 1, Figure 6). Monthly rainfall distributions are uneven, with little or no rainfall in the May, June, July, August and September. The maximum rainfall occurs in January, November, October and December (Figure 6). The daily maximum-recorded rainfall in the region was $96.2 \mathrm{~mm}$ on the $19^{\text {th }}$ of December 1985 [30].

The computed values and visual inspection revealed that Pearson Type III pdf produced the best fit in most of cases (Figure 7). The predicated maximal daily rainfall depth for 2, 3, 5, 10, 20, 50 and 100 return periods of Pearson Type 3 distribution is 
Table 1. Statistical analysis of daily rainfall data for the period from 1965 to 2004 at Tabuk Weather Station 403,750 Latitude: 28.38, Longitude: 36.63, Altitude: 778.

\begin{tabular}{cc}
\hline Parameters & Value \\
\hline Number of years & 49.00 \\
Minimum & 1.00 \\
Maximum & 96.20 \\
Average & 24.20 \\
Median & 20.00 \\
Standard deviation & 21.80 \\
Coefficient of variation $\left(C_{\mathrm{v}}\right)$ & 0.90 \\
Skewness coefficient of $\left(C_{\mathrm{s}}\right)$ & 1.53 \\
Kurtosis coefficient of $\left(C_{\mathrm{k}}\right)$ & 4.74 \\
\hline
\end{tabular}

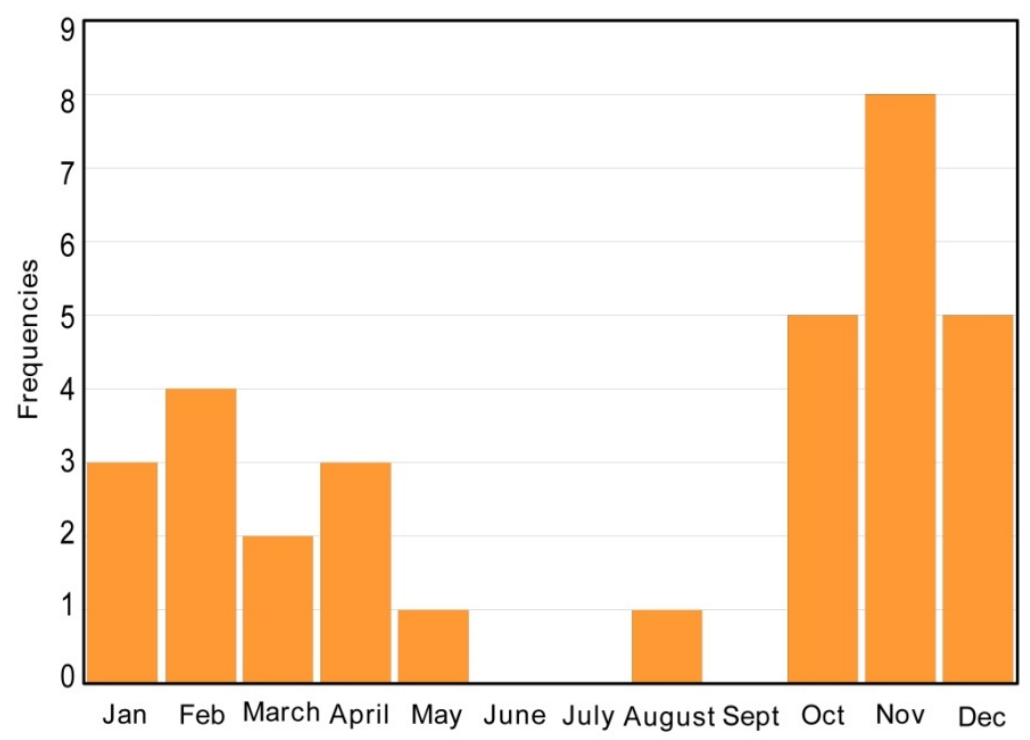

Figure 6. Statistical distribution of daily rainfall depth records over months of the year at Tabuk Weather Station 403,750.

presented in Table 2.

\subsubsection{Delineation of Drainage System}

Analysis DEM (Figure 8) of the area shows that the high lands occur towards the south, east, and the west of Tabuk area (Figure 9); the northern part occupies the relatively lower elevations towards Qa'a Sharawra. The general slope is towards the north $(0.13$ $\mathrm{m} / \mathrm{m}$ ). Flatness terrain present in the last eight kilometers of Tabuk city, starting from Arrawdah district to the northern border of Tabuk city, the slope is nearly $0.0002 \mathrm{~m} / \mathrm{m}$ (Figure 9).

WMS program was determined mainstream network and delineated the watershed of the Tabuk city and its environ (Figure 10(a)), also define and calculate the drainage area upstream of the outlet points of interest (selected outlet at the northern borders of Tabuk city). The wadis are generated from Nahamah Mountain in the southern part of the catchment. Generally, Tabuk city represents the lowland and consider the outlet of 


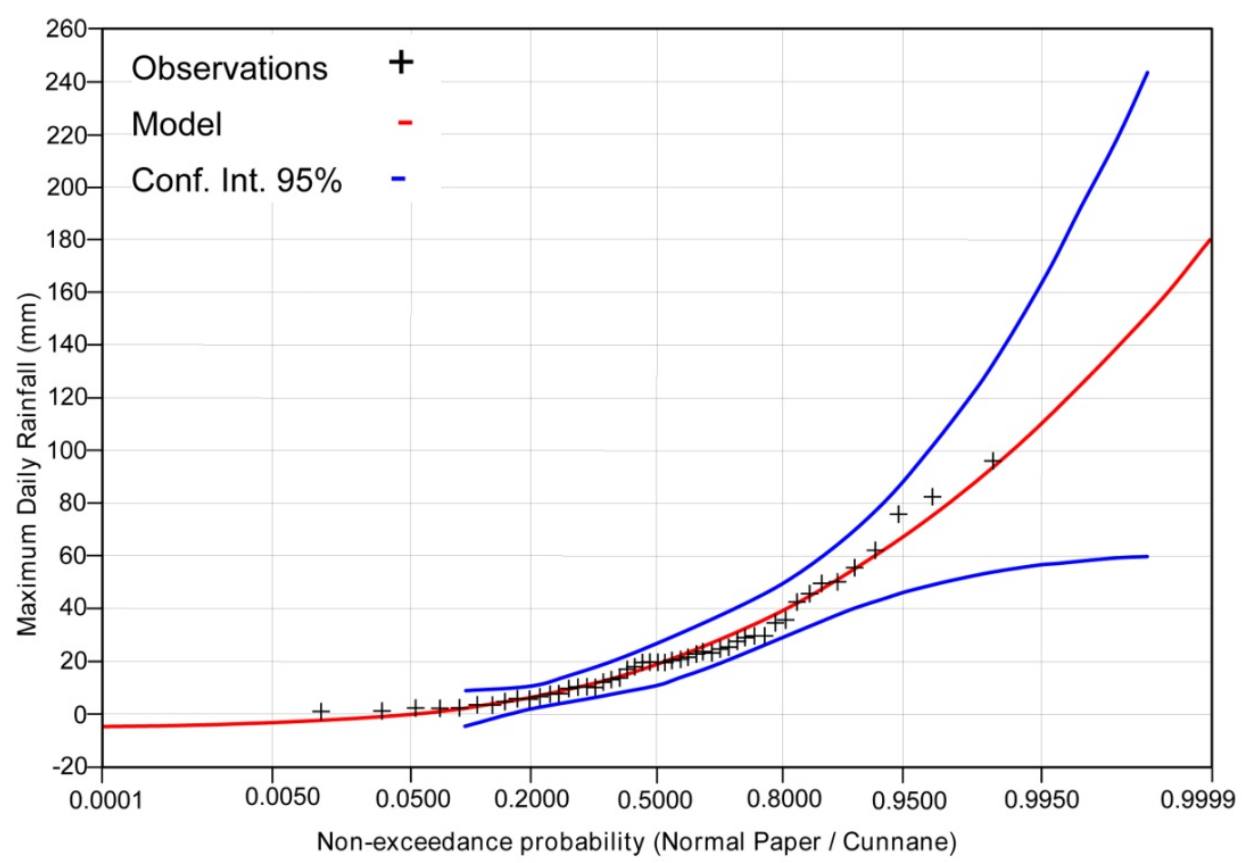

Figure 7. Gumbel distribution fit for annual maximum daily rainfall at Tabuk weather station 403,750 .

Table 2. Estimated return periods for maximum daily rainfall depth (Pearson Type III) for Tabuk weather station 403,750 .

\begin{tabular}{ccccc}
\hline $\begin{array}{c}\text { Return period } \\
\text { (years) }\end{array}$ & $\begin{array}{c}\text { Annual chance of } \\
\text { exceedance }\end{array}$ & $\begin{array}{c}\text { Rainfall depth } \\
(\mathrm{mm})\end{array}$ & SD & $\begin{array}{c}\text { Confidence } \\
\text { interval }\end{array}$ \\
\hline 100 & 0.9900 & 103.0 & 26.70 & $50.2-155$ \\
50 & 0.9800 & 89.4 & 20.50 & $49.2-130$ \\
20 & 0.9500 & 71.6 & 13.30 & $45.5-97.7$ \\
10 & 0.9000 & 57.6 & 9.06 & $39.8-75.4$ \\
5 & 0.8000 & 42.9 & 6.63 & $29.9-55.9$ \\
3 & 0.6667 & 31.7 & 5.88 & $20.2-43.3$ \\
2 & 0.5000 & 21.3 & 5.25 & $11.0-31.6$ \\
\hline
\end{tabular}

most wadis such as Wadi Abu Nushayfah, Wadi Na'am, Wadi Al Baqqar, Wadi Dab'an and Wadi Al Ghuwaul (Figure 10(a)).

Eight drainage basins (B-1, B-2, B-3, B-4, B-5, B-6, B-7 and B-8) affect on Tabuk city (Figure 10(b)). The upstream of all drainage basins have their source from outside Tabuk city, except the Basins 2 and 4 within the city. The downstream is towards the north at Qa'a Sharawra depression (Figure 10(b)). The main different morphological parameters of these basins indicated that most of the basins are elongated, with low relief, and moderate drainage density (Table 3 ).

Tabuk city lies in the downstream of the middle basin Number 3 (Figure 10(b)). It is a bigger and more effect basin; it occupies an area of about $2860 \mathrm{~km}^{2}$. The basin comprises Wadi Na'am and Al Baqqar in the south, these were connected together to form Wadi Dab'an within Tabuk city. It is passing cross the center of the city and influential 


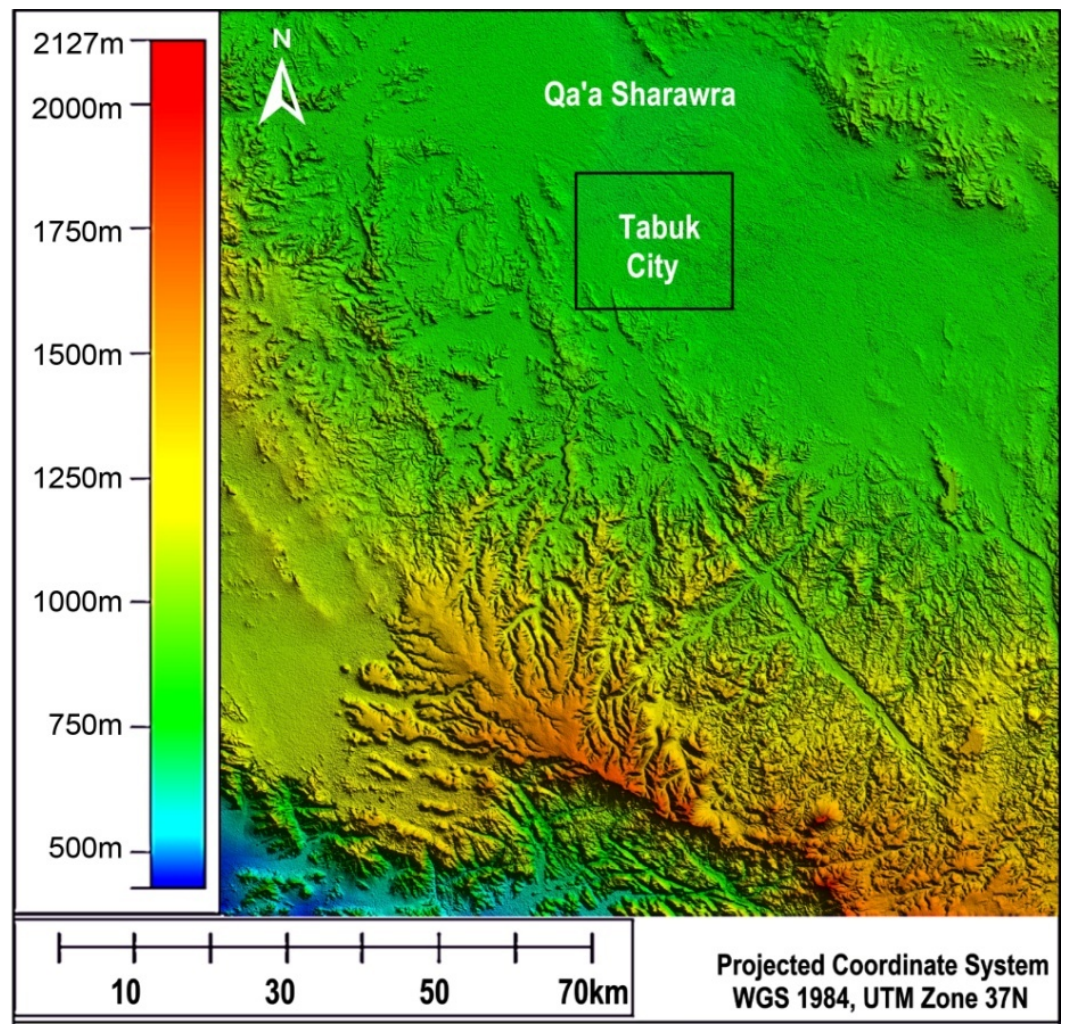

Figure 8. Shuttle radar topography mission (SRTM v.3, 1 arc) 30-m DEM (projected coordinate system: WGS_1984_UTM_Zone_37N) of Tabuk, KSA.

Table 3. The main basins geometric parameters of Tabuk area, KSA.

\begin{tabular}{cccccccccc}
\hline Parameter & Unit & B-1 & B-2 & B-3 & B-4 & B-5 & B-6 & B-7 & B-8 \\
\hline Basin area & $\mathrm{km}^{2}$ & 1519.67 & 24.46 & 2860.11 & 8.53 & 1185.08 & 206.31 & 57.33 & 44.07 \\
Basin length & $\mathrm{km}$ & 66.45 & 13.98 & 95.87 & 6.40 & 87.71 & 54.85 & 22.02 & 12.65 \\
Basin slopes & $\mathrm{m} / \mathrm{m}$ & 0.0811 & 0.0219 & 0.1384 & 0.2200 & 0.0910 & 0.0255 & 0.0268 & 0.0244 \\
Periphery & $\mathrm{km}$ & 324.26 & 56.12 & 434.45 & 25.73 & 380.05 & 230.62 & 95.55 & 52.15 \\
Shape & & 2.910 & 7.990 & 3.210 & 4.800 & 6.490 & 14.580 & 8.460 & 3.630 \\
Sinusitis & $\mathrm{msl} / 1$ & 1.810 & 0.960 & 1.560 & 0.940 & 1.540 & 1.470 & 1.290 & 1.400 \\
Av. overland flow & $\mathrm{m}$ & 1159.52 & 1333.33 & 1036.38 & 1222.11 & 1049.19 & 1053.57 & 1203.76 & 1019.41 \\
Mean basin & $\mathrm{m}$ & 928.54 & 750.10 & 1113.04 & 747.58 & 953.14 & 808.32 & 766.67 & 765.00 \\
elevation & & & & & & & & & \\
Max. flow distance & $\mathrm{km}$ & 123.56 & 18.23 & 152.72 & 8.71 & 138.56 & 83.60 & 32.97 & 20.50 \\
Max. flow slope & $\mathrm{m} / \mathrm{m}$ & 0.0038 & 0.0019 & 0.0057 & 0.0020 & 0.0048 & 0.0022 & 0.0016 & 0.0016 \\
Max. stream length & $\mathrm{km}$ & 120.09 & 13.46 & 149.49 & 5.99 & 135.43 & 80.43 & 28.48 & 17.74 \\
Max. stream slope & $\mathrm{m} / \mathrm{m}$ & 0.0036 & 0.0010 & 0.0045 & 0.0014 & 0.0041 & 0.0015 & 0.0017 & 0.0013 \\
\hline
\end{tabular}

on the most of Tabuk districts. Basin 5, which includes Wadi Abu Nushayfah and Ghudayy, is the second dangerous basin on Tabuk city districts from the east. The northwest part of Tabuk city is affected by basin 1 of Wadi Ghuwaul; the basin has area of about $1520 \mathrm{~km}^{2}$. Whatever, Basins 2, 4, 7 and 8 are affecting the farthest northern, eastern, and northwestern borders of the city. Due to the large areas of the Basins 3,1 


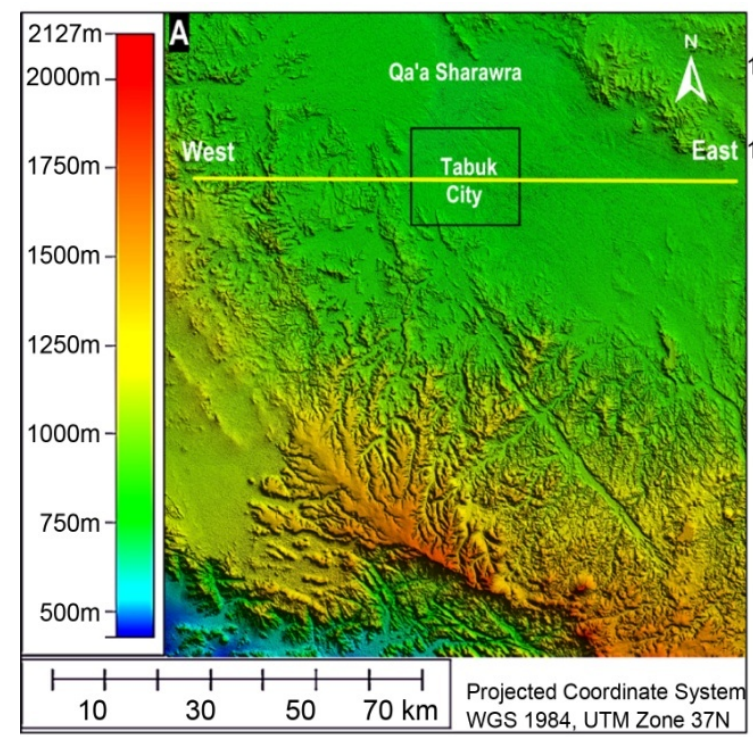

From Pos: 212193.886, 3144491.022

To Pos: $301563.778,3144798.006$
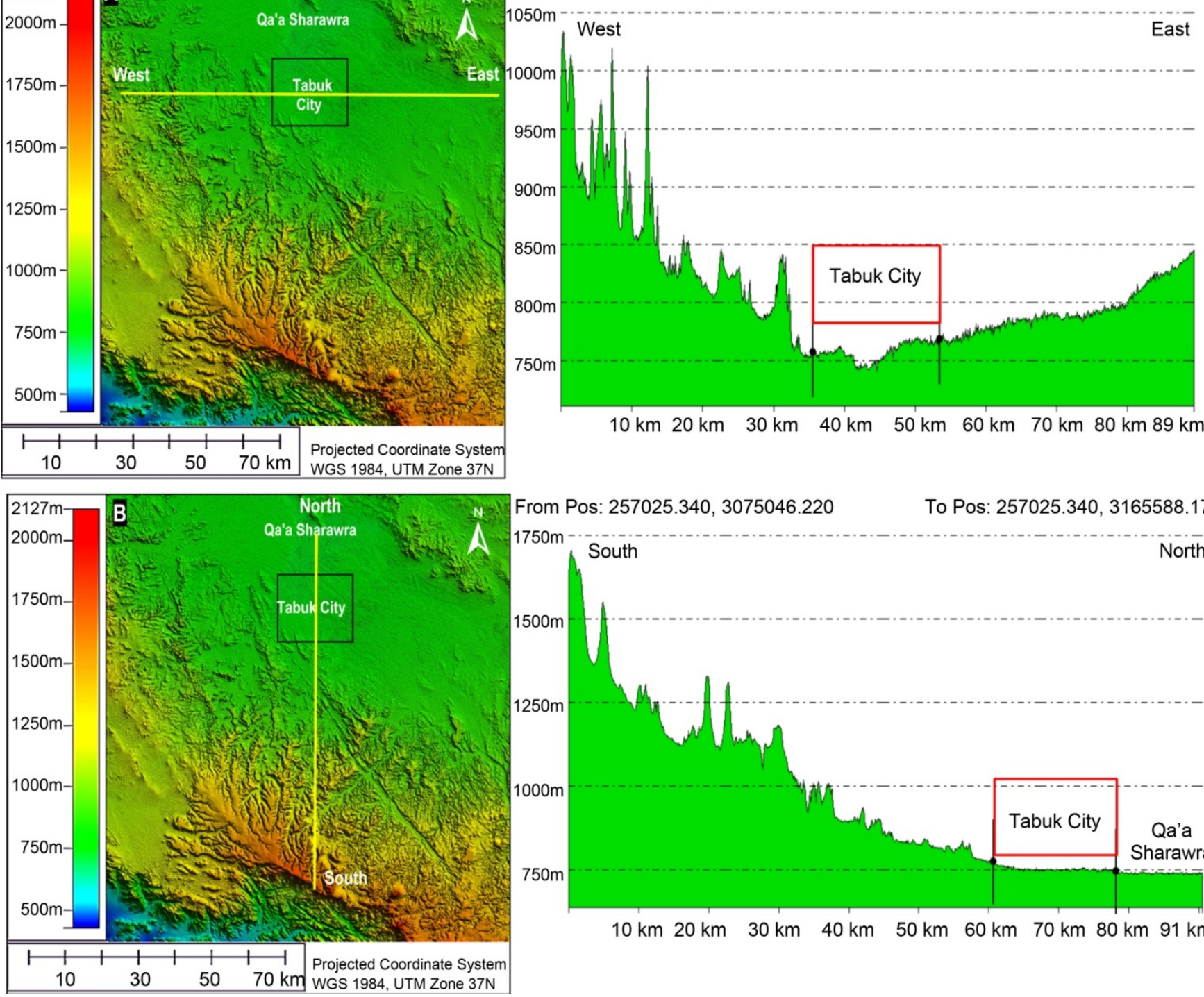

From Pos: $257025.340,3075046.220$

To Pos: $257025.340,3165588.177$

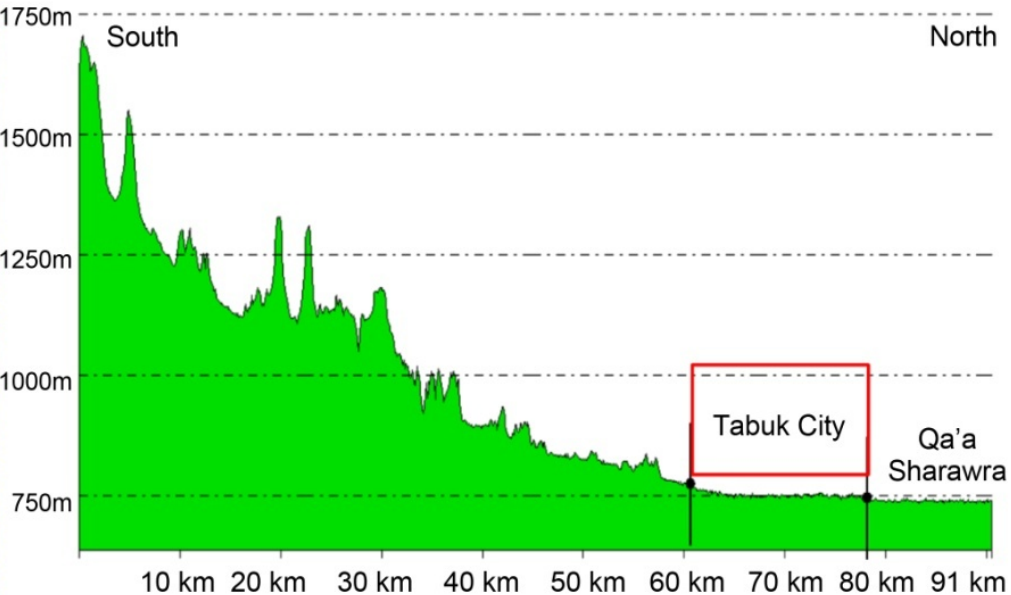

Figure 9. Cross section of Tabuk area from West to East (A), longitudinal section from South to North (B) Tabuk, KSA.

and $5\left(2860,1520 \& 1185 \mathrm{~km}^{2}\right.$, respectively), the maximum surface runoff values are expected to be high. Therefore, the flood and surface runoff behavior in these wadis are important for any flood protection projects.

\subsubsection{Peak Discharge}

The results of the peak discharge and volume of runoff estimated for return periods of $2,3,5,10,20,50$ and 100 years from the run of the HEC-1 model of the drainage basins at the outlet of Tabuk area are represented in Table 4. From the hydrograph (Figure 11 ), it is noticed that the discharge rate of the drainage basins is highly variable from one basin to another, according to the basin area. Three basins (B-3, B-1 and B-5) have a high peak discharge and volume of runoff. The maximum peak discharge for the lowest return periods of 2 year of the Basins 3, 1 and 5 are $41.19,20.39$ and $15.5 \mathrm{~m}^{3} / \mathrm{s}$, respectively, whatever for the highest return period 100 year are 2201, 1085 and $824 \mathrm{~m}^{3} / \mathrm{s}$, respectively (Table 4 and Figure 11). 

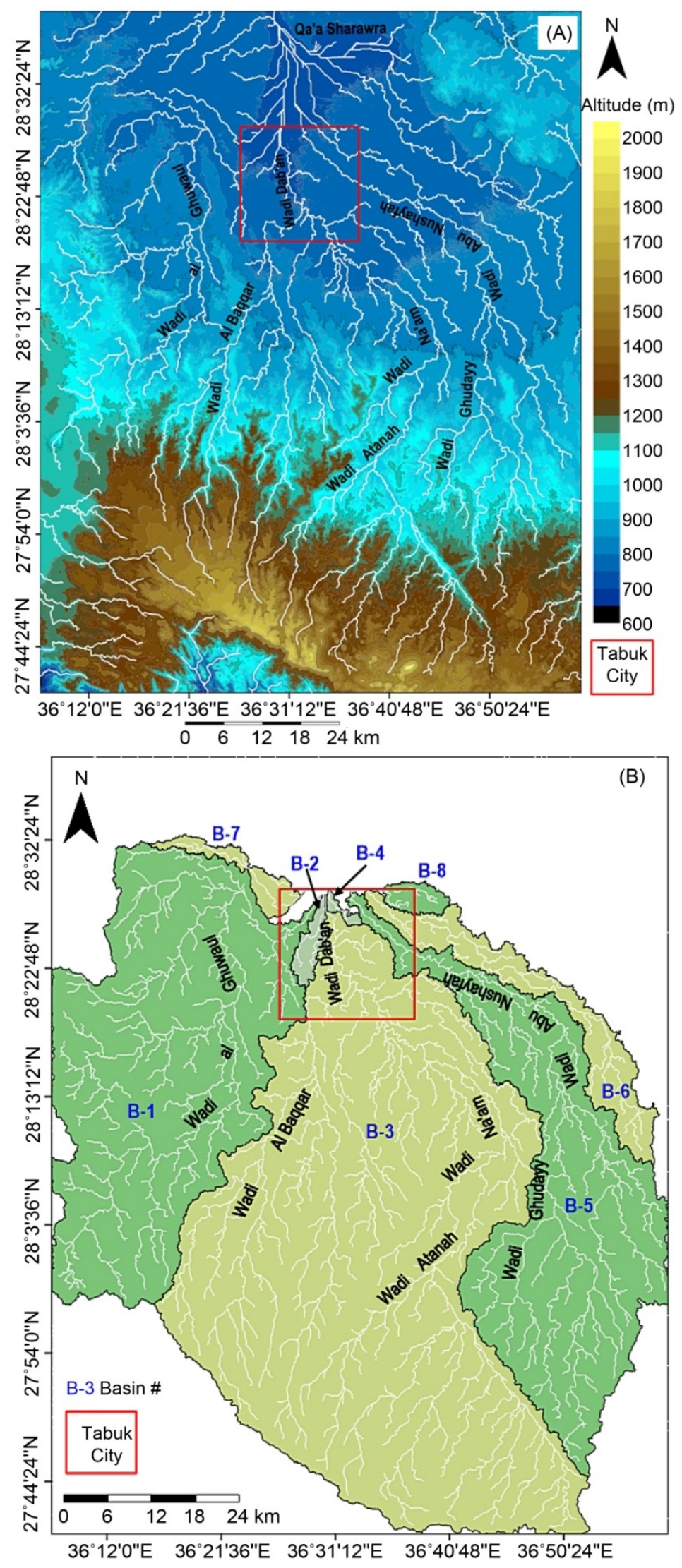

Figure 10. Drainage system combined with DEM (A), basins effect on Tabukcity (B), Tabuk area, KSA. 
Flow vs. Time

PEAK: $1084.62 \mathrm{cms}$ TIME OF PEAK: 1650 min VOLUME: $80549817.00 \mathrm{~m}^{\wedge} 3$

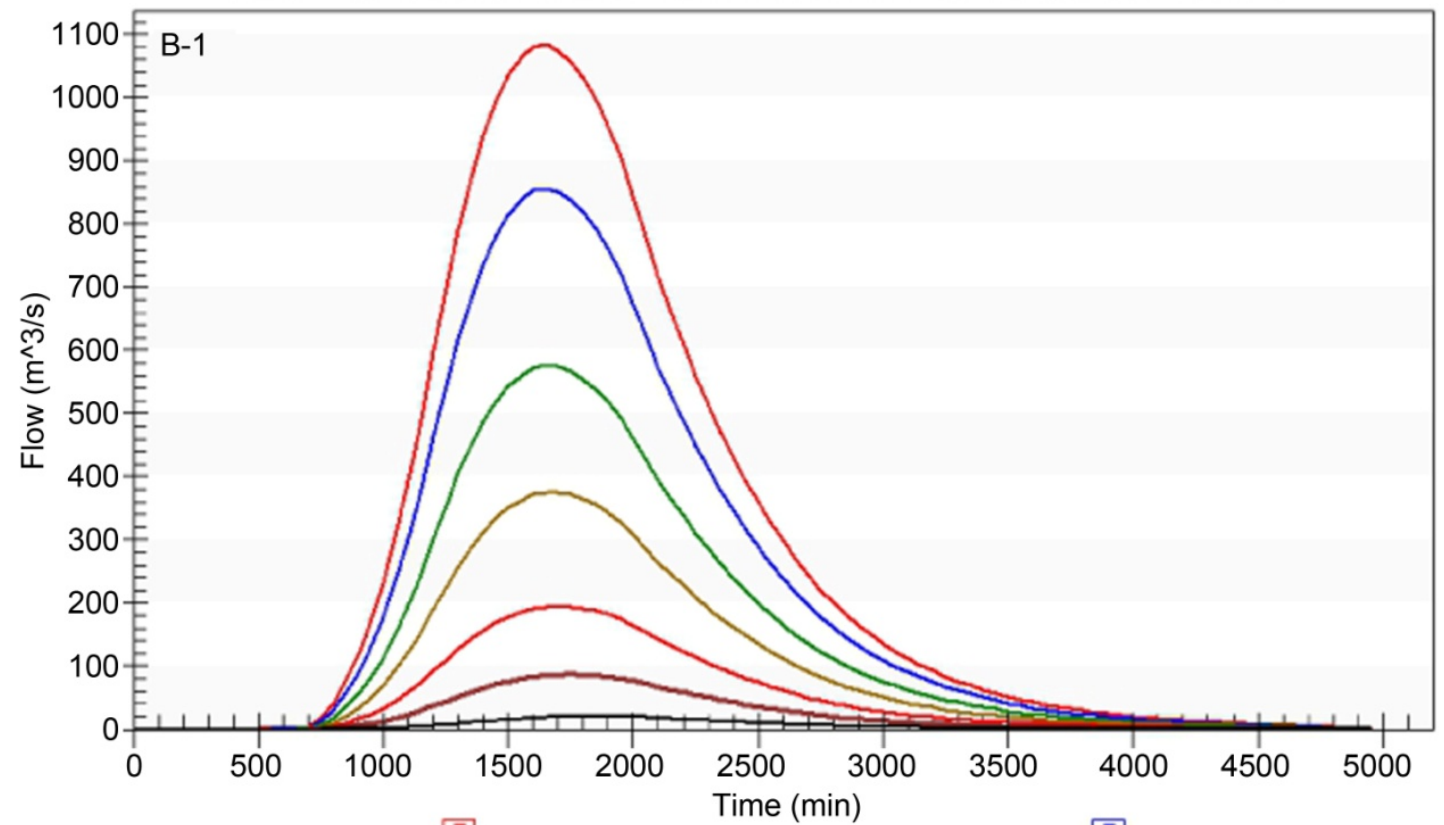

100-year, 1 B Ratio 1, P:1084.62, T:1650, V:80549817.0 50-year, 1B Ratio 1, P:856.91, T:1650, V:63750567.0 7 1

20-year, 1B Ratio 1, P:576.40, T:1650, V:43060884.0 10-year, 1B Ratio 1, P:375.92, T:1650, V:28254538.5

5-year, 1B Ratio 1, P:195:07, T:1700, V:14787093.0 3-year, 1B Ratio 1, P:86.82, T:1750, V:6647139.0

5-year, 1B Ratio 1, P:195.07, T:1700, V:14787093.0 3-year, 1B Ratio 1, P:86.82, T:1750, V:6647139.0

2-year, $1 B$ Ratio 1, P:20.39, T:1850, V:1558012.5

\section{HEC-1}

PEAK: $34.98 \mathrm{cms}$ TIME OF PEAK: 1100 min VOLUME: $1294770.75 \mathrm{~m}^{\wedge} 3$

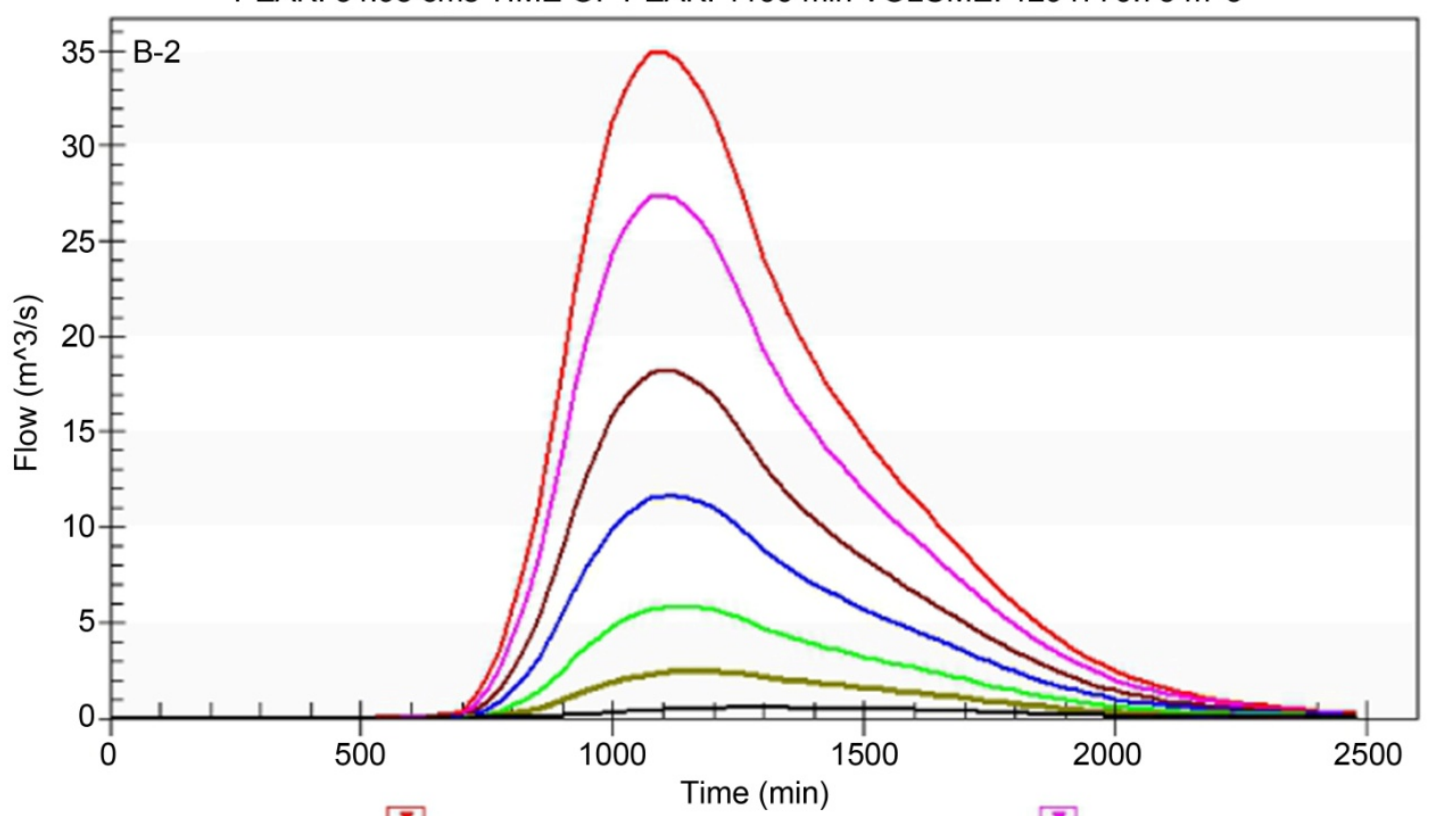

100-year, 2B Ratio 1, P:34.98, T:1100, V:1294770.8 $\mathbf{7}$

50-year, 2B Ratio 1, P:27.47, T:1100, V:1024667.3 20-year, 2B Ratio 1, P:18.23, T:1100, V:692028.8 5-year, 2B Ratio 1, P:5.85, T:1125, V:237534.0 0-year, 2B Ratio 1, P:11.67, T:1100, V:453999.8 $\mathbf{7}$ 3-year, 2B Ratio 1, P:2.47, T:1175, V:106727.3

2-year, 2B Ratio 1, P:0.52, T:1275, V:24978.8 
Flow vs. Time

PEAK: $2201.25 \mathrm{cms}$ TIME OF PEAK: $1530 \mathrm{~min}$ VOLUME: $151574352.30 \mathrm{~m}^{\wedge} 3$

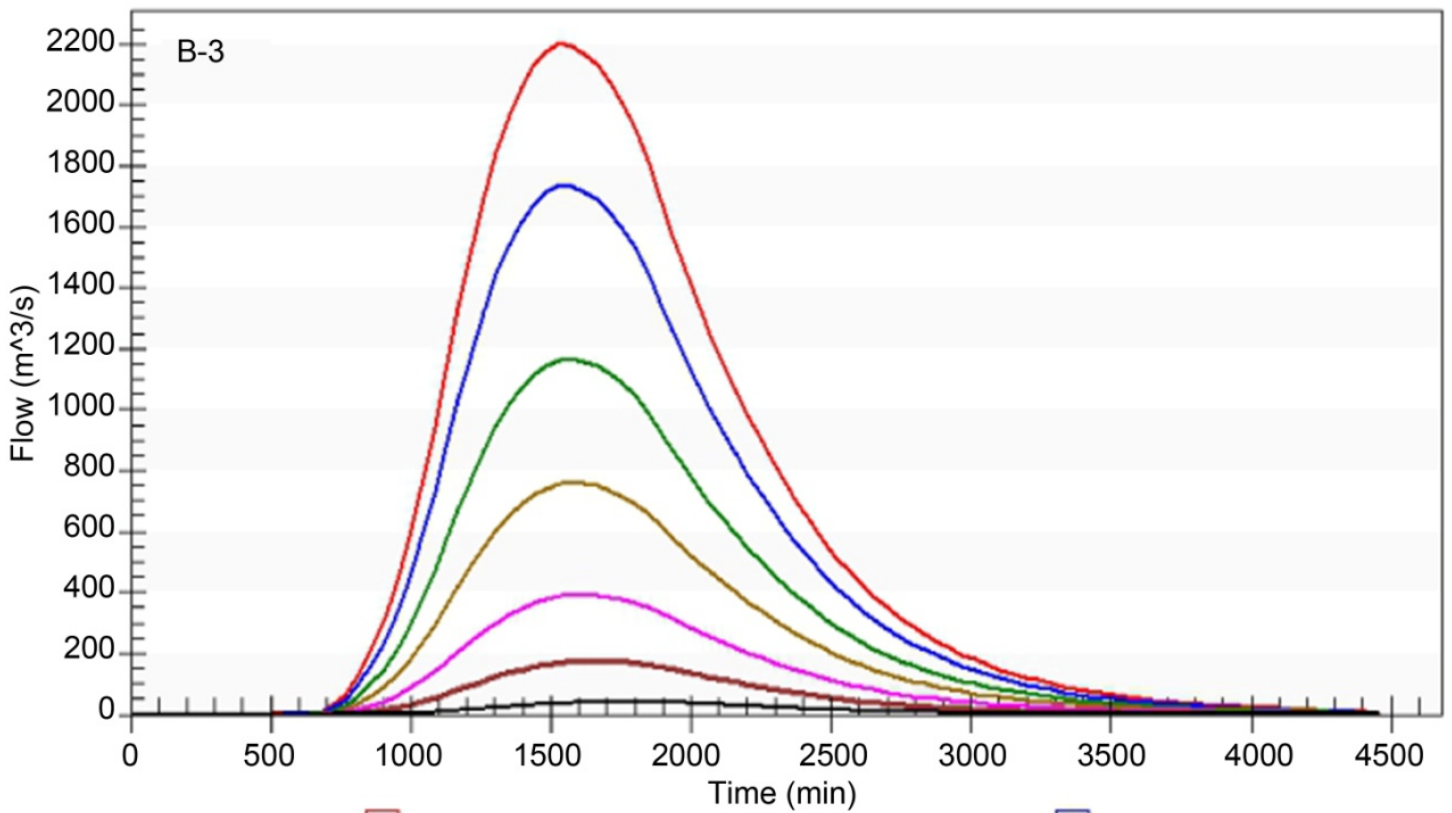

100-year, 3B Ratio 1, P:2201.25, T:1530, V:151574352.3 50-year, 3B Ratio 1, P:1735.69, T:1530, V:119961286.2 20-year, 3B Ratio 1, P:1165.39, T:1575, V:81027498.2 10-year, 3B Ratio 1, P:759.47, T:1575, V:53165355.8 T 7

5-year, 3B Ratio 1, P:392.94, T:1620, V:27823185.4 3-year, 3B Ratio 1, P:174.90, T:1665, V:12506459.4

2-year, 3B Ratio 1, P:41.19, T:1755, V:2930891.9

Flow vs. Time

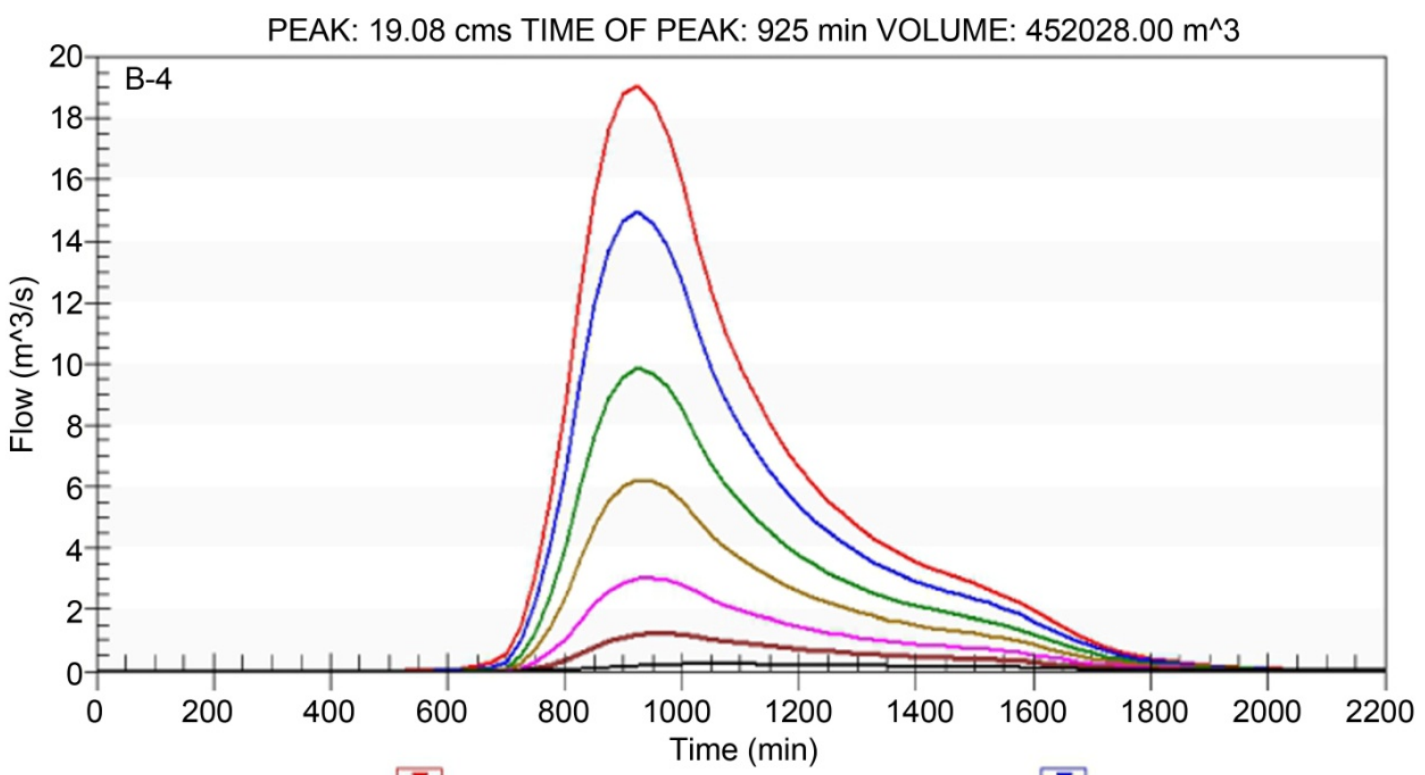

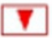

100-year, 4B Ratio 1, P:19.08, T:925, V:452028.0 $\nabla$

20-year, 4B Ratio 1, P:9.86, T:925, V:241647.0

$\nabla$

5-year, 4B Ratio 1, P:3.04, T:950, V:82987.5

$\mathbf{T}$
T

50-year, 4B Ratio 1, P:14.95, T:925, V:357747.0 $\nabla$

10-year, 4B Ratio 1, P:6.24, T:925, V:158562.0 T

3-year, 4B Ratio 1, P:1.22, T:975, V:37306.5

2-year, 4B Ratio 1, P:0.22, T:1025, V:8749.5 
Flow vs. Time

PEAK: $823.63 \mathrm{cms}$ TIME OF PEAK: $1650 \mathrm{~min}$ VOLUME: $62802054.00 \mathrm{~m}^{\wedge} 3$

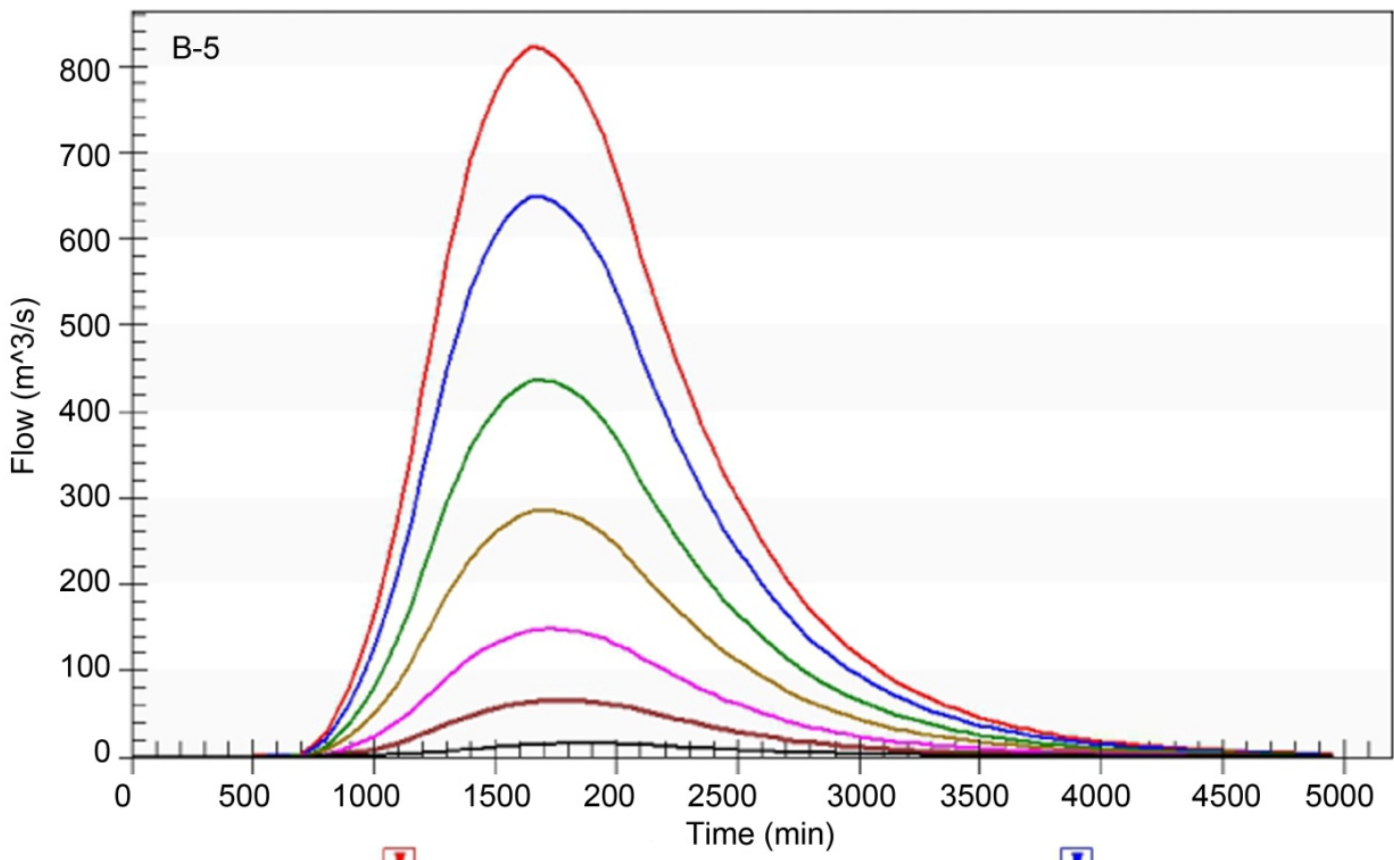

100-year, 5B Ratio 1, P:823.63, T:1650, V:62802054.0 50-year, 5B Ratio 1, P:650.20, T:1650, V:49703878.5 20-year, 5B Ratio 1, P:437.00, T:1700, V:33572484.0 10-year, 5B Ratio 1, P:285.49, T:1700, V:22028350.5 5-year, 5B Ratio 1, P:148.09, T:1750, V:11528280.0

2-year, 5B Ratio 1, P:15.50, T:1900, V:1214469.0

Flow vs. Time

PEAK: $117.52 \mathrm{cms}$ TIME OF PEAK: $1870 \mathrm{~min}$ VOLUME: $10913010.90 \mathrm{~m}^{\wedge} 3$

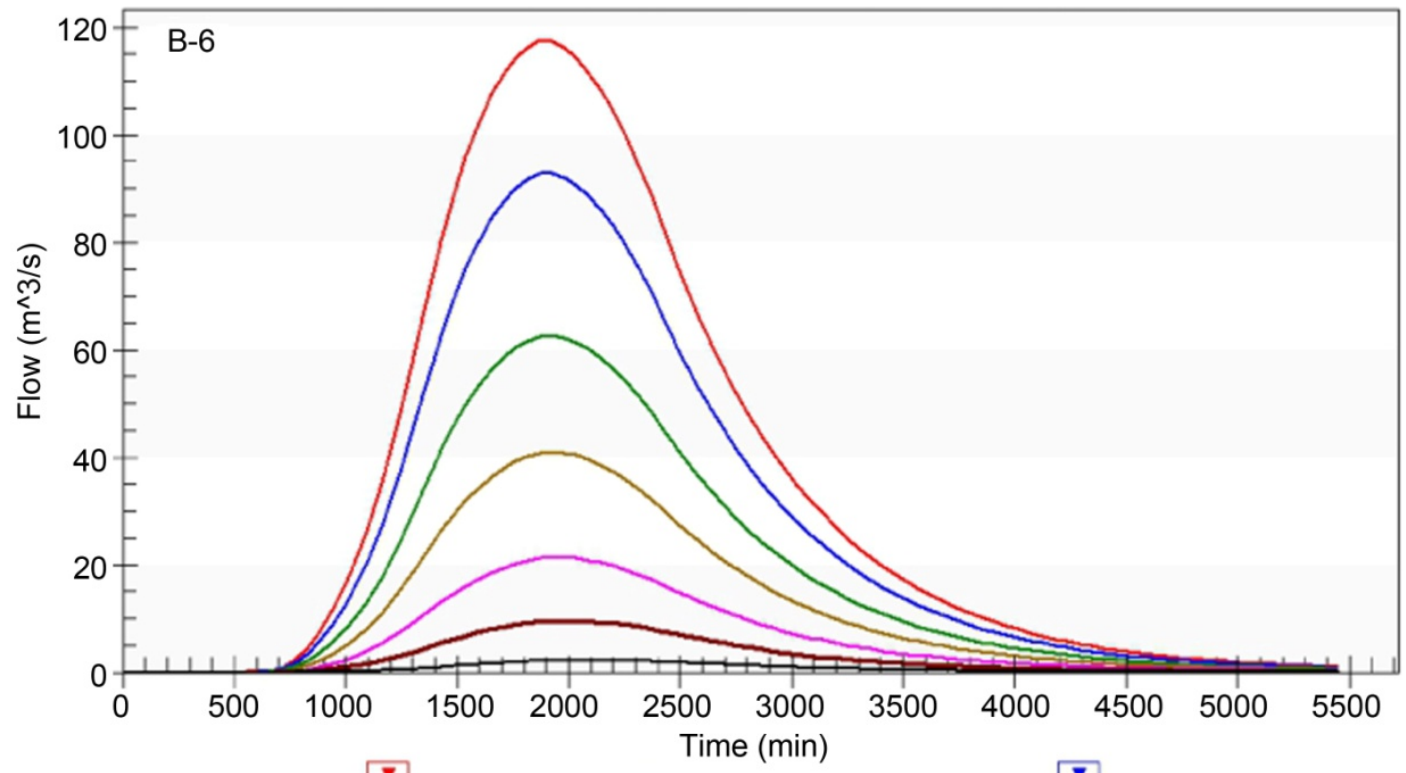

100-year, 6B Ratio 1, P:117.52, T:1870, V:10913010.9 20-year, 6B Ratio 1, P:62.62, T:1925, V:5833464.4 T

$35, T \cdot 1925, V \cdot 2002903$

5-year, 6B Ratio 1, P:21.35, T:1925, V:2002903.6

50-year, 6B Ratio 1, P:92.85, T:1870, V:8636776.5 10-year, 6B Ratio 1, P:40.99, T:1925, V:3827417.5 3-year, 6B Ratio 1, P:9.56, T:1980, V:900207.0

2-year, 6B Ratio 1, P:2.25, T:2090, V:210917.9 
Flow vs. Time

PEAK: $61.17 \mathrm{cms}$ TIME OF PEAK: $1260 \mathrm{~min}$ VOLUME: $3030476.40 \mathrm{~m}^{\wedge} 3$

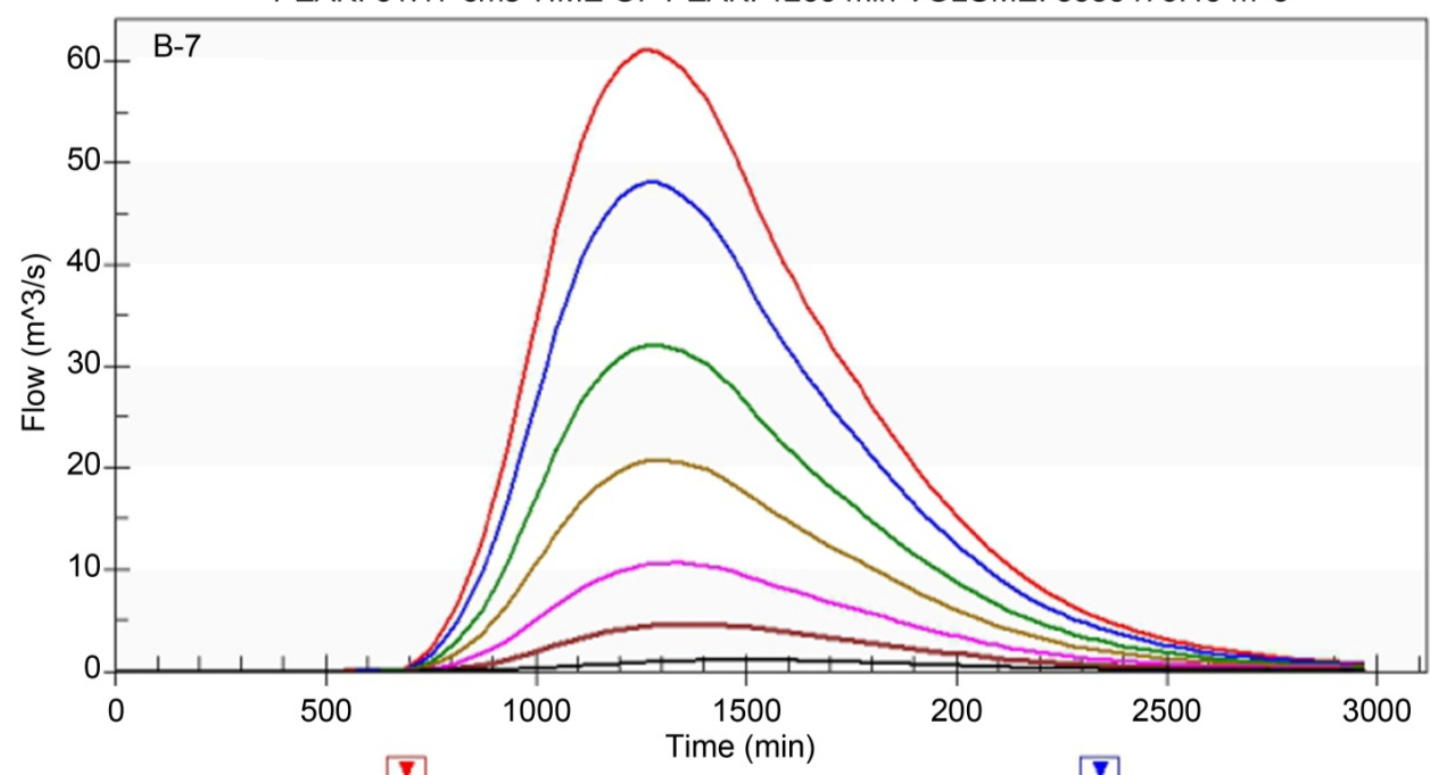

100-year, 7B Ratio 1, P:61.17, T:1260, V:3030476.4 50-year, 7B Ratio 1, P:48.09, T:1260, V:2398219.2 20-year, 7B Ratio 1, P:32.06, T:1290, V:1619623.8 5-year, 7B Ratio 1, P:10.55, T:1320, V:555876.9 10-year, 7B Ratio 1, P:20.71, T:1290, V:1062504.9 5-year, 7B Ratio 1, P:10.55, T:1320, V:555876.9
2-year, 7B Ratio 1, P:1.05, T:1500, V:58451.4 3-year, 7B Ratio 1, P:4.59, T:1380, V:249728.4

Flow vs. Time PEAK: $60.56 \mathrm{cms}$ TIME OF PEAK: $1110 \mathrm{~min}$ VOLUME: $2336087.70 \mathrm{~m}^{\wedge} 3$

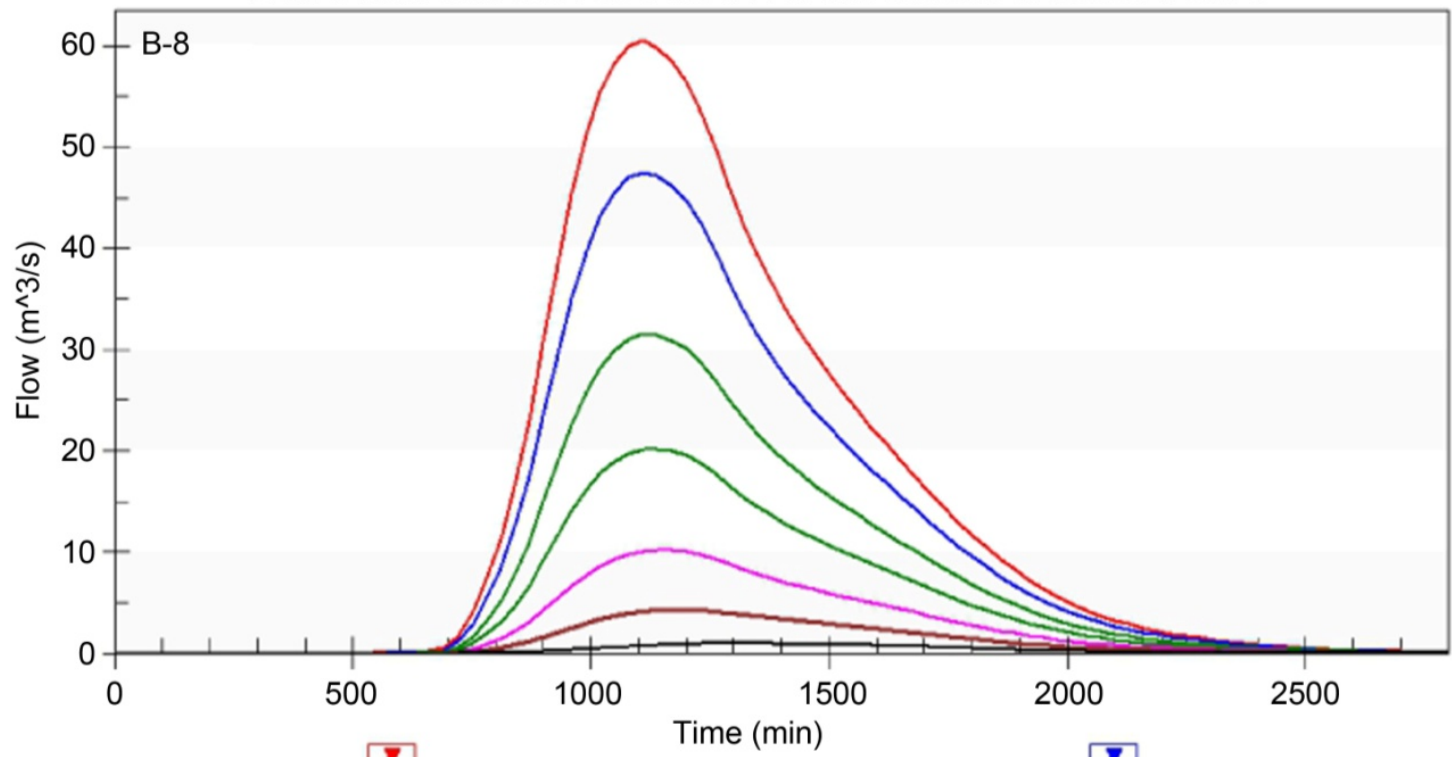

$\nabla$

100-year, 8B Ratio 1, P:60.56, T:1110, V:2336087.7 $\nabla$

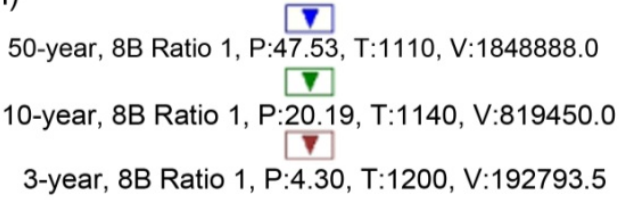

5-year, 8B Ratio 1, P:10.14, T:1140, V:428864.4

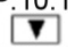

3-year, 8B Ratio 1, P:4.30, T:1200, V:192793.5

2-year, 8B Ratio 1, P:0.92, T:1290, V:45198.0

Figure 11. Outflow Hydrograph of drainage basins for return period (2, 3, 5, 10, 20, 50 and 100 years), of Tabuk City, Tabuk, KSA. 
Table 4. Measured peak flood discharge and volume of runoff values of the drainage basins for return period $(2,3,5,10,20,50$ and 100 years) of Tabuk region, KSA.

\begin{tabular}{|c|c|c|c|c|c|c|c|c|c|}
\hline \multicolumn{3}{|c|}{ Return Period (Years) } & 100 & 50 & 20 & 10 & 5 & 3 & 2 \\
\hline \multirow{2}{*}{ B-1 } & $\mathrm{Qp}^{\mathrm{a}}$ & $\mathrm{m}^{3} / \mathrm{s}$ & 1084.62 & 856.91 & 576.4 & 375.92 & 195.07 & 86.82 & 20.39 \\
\hline & $\mathrm{V}^{\mathrm{b}}$ & $\mathrm{m}^{3}$ & $80,549,817$ & $63,750,567$ & $43,060,884$ & $28,254,538$ & $14,787,093$ & $6,647,139$ & $1,558,012$ \\
\hline \multirow{2}{*}{ B-2 } & Qp & $\mathrm{m}^{3} / \mathrm{s}$ & 34.77 & 27.25 & 18.04 & 11.57 & 5.79 & 2.45 & 0.52 \\
\hline & $\mathrm{V}$ & $\mathrm{m}^{3}$ & $1,296,918$ & $1,026,449$ & 693,334 & 454,938 & 238,101 & 107,040 & 25,091 \\
\hline \multirow{2}{*}{ B-3 } & Qp & $\mathrm{m}^{3} / \mathrm{s}$ & 2201.25 & 1735.69 & 1165.39 & 759.47 & 392.94 & 174.9 & 41.19 \\
\hline & $\mathrm{V}$ & $\mathrm{m}^{3}$ & $151,574,352$ & $119,961,286$ & $81,027,498$ & $53,165,355$ & $27,823,185$ & $12,506,459$ & $2,930,891$ \\
\hline \multirow{2}{*}{ B-4 } & Qp & $\mathrm{m}^{3} / \mathrm{s}$ & 19.08 & 14.95 & 9.86 & 6.24 & 3.04 & 1.22 & 0.22 \\
\hline & $\mathrm{V}$ & $\mathrm{m}^{3}$ & 452,028 & 357,747 & 241,647 & 158,562 & 82,987 & 37,306 & 8749 \\
\hline \multirow{2}{*}{ B-5 } & Qp & $\mathrm{m}^{3} / \mathrm{s}$ & 823.63 & 650.2 & 437 & 285.49 & 148.09 & 65.97 & 15.5 \\
\hline & $\mathrm{V}$ & $\mathrm{m}^{3}$ & $62,802,054$ & $49,703,878$ & $33,572,484$ & $22,028,350$ & $11,528,280$ & $5,182,032$ & $1,214,469$ \\
\hline \multirow{2}{*}{ B-6 } & Qp & $\mathrm{m}^{3} / \mathrm{s}$ & 117.52 & 92.85 & 62.62 & 40.99 & 21.35 & 9.56 & 2.25 \\
\hline & $\mathrm{V}$ & $\mathrm{m} 3$ & $10,913,010$ & $8,636,776$ & $5,833,464$ & $3,827,417$ & $2,002,903$ & 900,207 & 210,917 \\
\hline \multirow{2}{*}{ B-7 } & Qp & $\mathrm{m}^{3} / \mathrm{s}$ & 61.17 & 48.09 & 32.06 & 20.71 & 10.55 & 4.59 & 1.05 \\
\hline & $\mathrm{V}$ & $\mathrm{m}^{3}$ & $3,030,476$ & $2,398,219$ & $1,619,623$ & $1,062,504$ & 555,876 & 249,728 & 58,451 \\
\hline \multirow{2}{*}{ B-8 } & Qp & $\mathrm{m}^{3} / \mathrm{s}$ & 60.56 & 47.53 & 31.52 & 20.19 & 10.14 & 4.3 & 0.92 \\
\hline & $\mathrm{V}$ & $\mathrm{m}^{3}$ & $2,336,087$ & $1,848,888$ & $1,248,862$ & 819,450 & 428,864 & 192,793 & 45,198 \\
\hline
\end{tabular}

${ }^{\mathrm{a}} \mathrm{Qp}$ : Peak discharge $\left(\mathrm{m}^{3} / \mathrm{sec}\right) ;{ }^{\mathrm{b}} \mathrm{V}$ : Volume of Runoff $\left(\mathrm{m}^{3}\right)$.

\section{Discussion}

The hazards posed by expansive soils have significant relation with water runoff. It leads to water accumulation or ponding, which can provide a source of moisture for expansive soil by infiltration. In Tabuk city, some parts of the watershed have runoff or flash floods on areas comprise expansive soil and hence the problem is duplicated due to first the flash flood and second the heaving of the soil. On the other hand, some locations have no flow, consequently no problems from this point of view even if the expansion soil is found. Volume of surface runoff can give singe of the potential swelling soil locations, where the expansion is linearly related to surface runoff.

The drainage pattern represented in. Delineating the drainage pattern effect on Tabuk districts is helpful in determining the directions of running water and the possible locations for accumulation (Figure 12(a)). The flow direction of surface runoff or storm water discharge should be away from the expansion soil zones. Therefore, the integration was carried out between geotechnical distribution of the expanded soil and the drainage network over Tabuk neighborhoods (Figure 12(b)). Consequently, the riskiest zones in the Tabuk city have been identified (Figure 13). It found that, the main watercourse of Wadi Dab'an and Abu Nushayfah passes through area contains expansive shale.

The residential neighborhoods built on the expansive shale in the middle part of Tabuk city affected by surface runoff flow of the tributaries of basins of Wadi Abu Nushayfah, Na'am and Atanah outlet, represent high-risk zones. These high-risk residential 

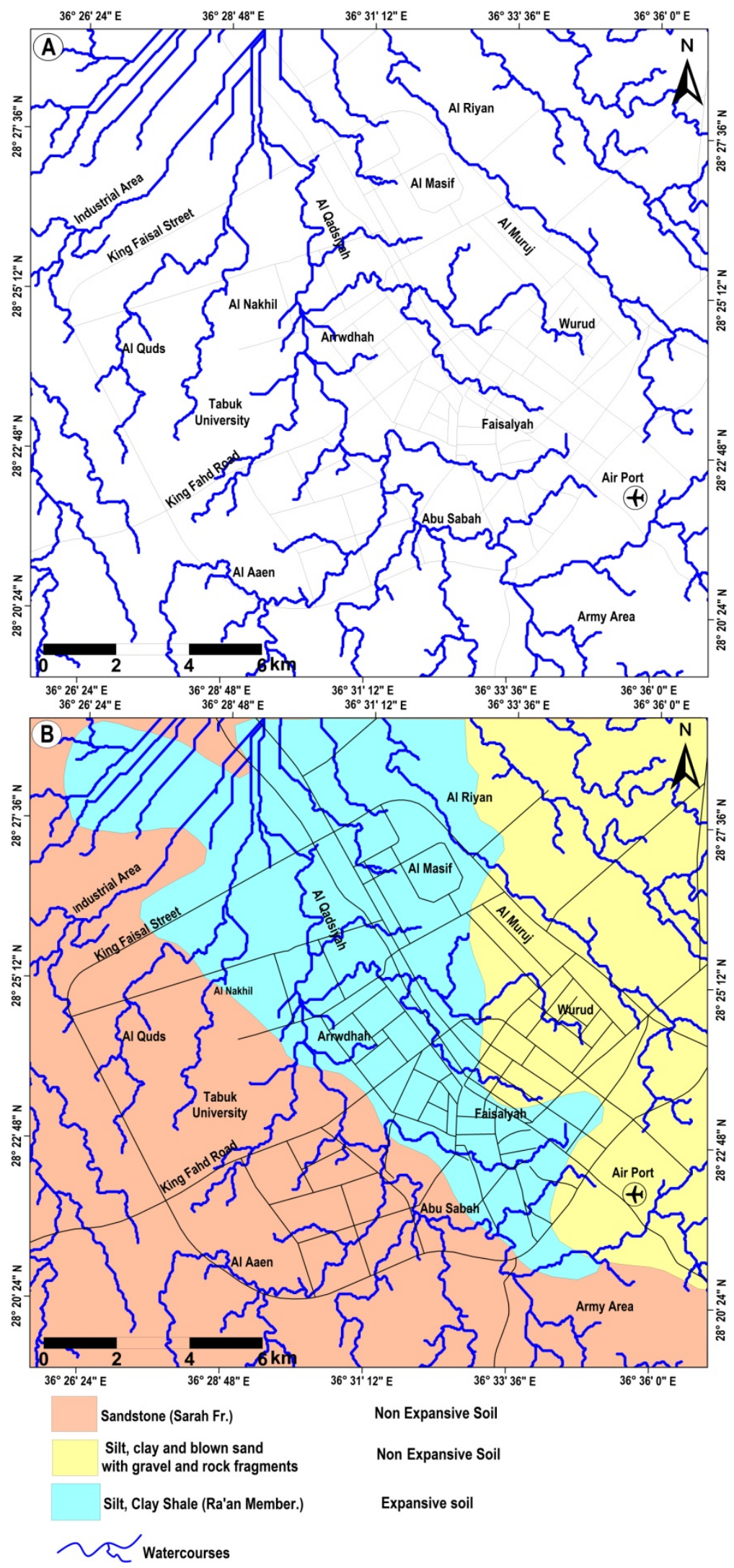

Figure 12. Drainage system overly on Tabuk districts (A) and integration between geotechnical distribution of the expanded soil and the drainage network (B) Tabuk city, KSA. 


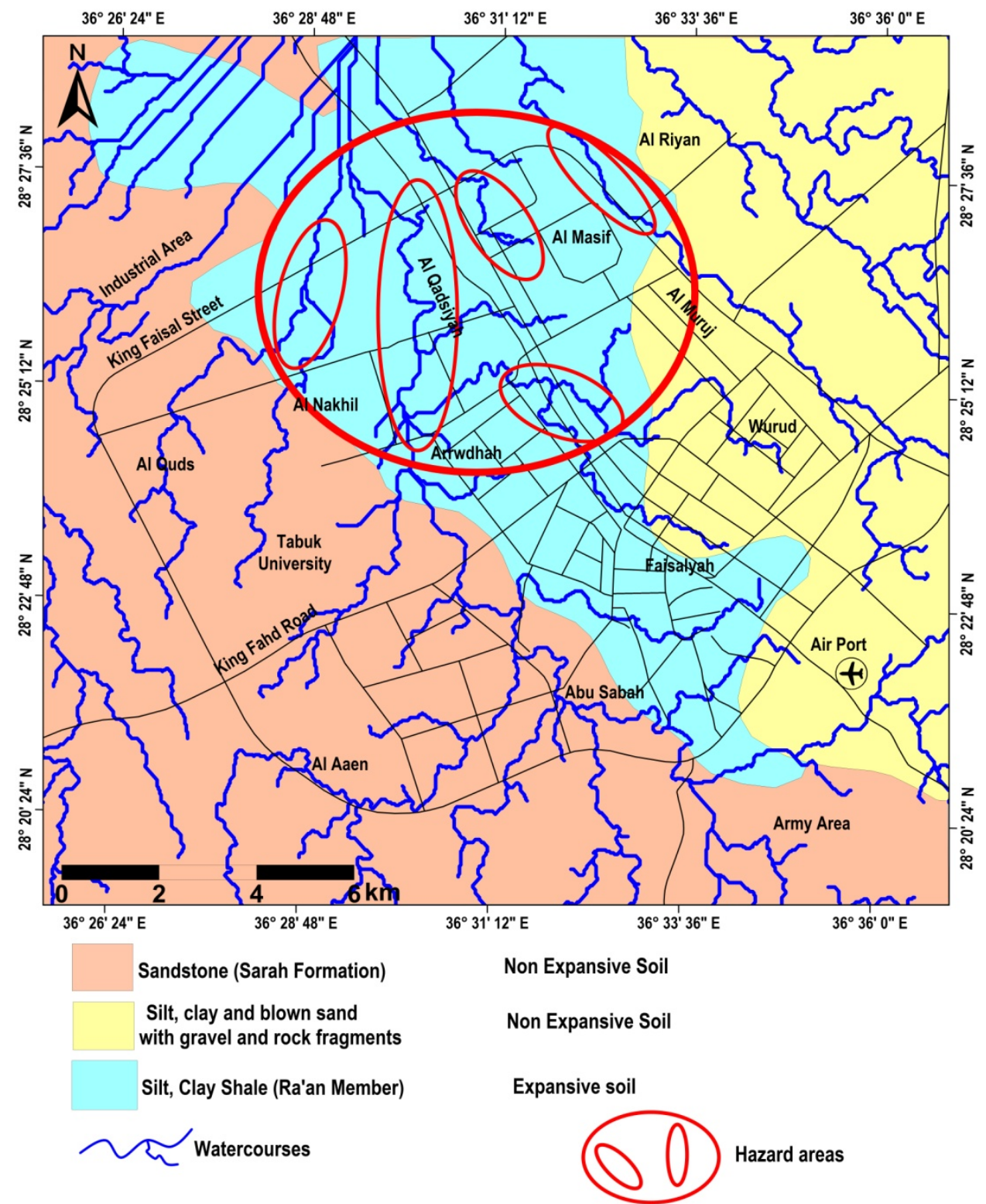

Figure 13. Hazard map of expansive shale over Tabuk districts, Tabuk, KSA.

neighborhoods are Al Qadsiyah, Al Maseif, Arrwdah, Al Nakhil and Al Rajhi (Figure 13). Flatness in the last eight kilometers of the basin (B-3) of Wadi Dab'an is starting from Arrawdah district to the north. It reduces surface runoff velocity and hence increases accumulation and stagnant water for a long time over the expansive soil, consequently maximizing the heaving of the expansive shale. The low-risk zones includes the western and the eastern neighborhoods (Figure 13), it is built on non-expansion soil or/rock (sandstone rocks in the west and silt, sand with boulders cobble rocks in the east).

\section{Conclusions}

Tabuk city contains expanded shale, in the central part of the city. It expands when it absorbs more water and creates the potential to exert enough force on a building or 
other structures to cause damage. In addition, Tabuk city exposed too many flash floods, mainly from large drainage basin of Wadi Na'am, Al Baqqar and Dab'an which covered an area of about $2860 \mathrm{~km}^{2}$ and had high peak discharge and volume of runoff $2201 \mathrm{~m}^{3} / \mathrm{s}$ and $151,574,352 \mathrm{~m}^{3}$, respectively and $41.19 \mathrm{~m}^{3} / \mathrm{s}$ and $2,930,891 \mathrm{~m}^{3}$ for returned period 100 and 2 years, respectively. In the event of flash floods or surface runoff, water flows and collects in some places that contain the expanded shale, causing its expansion and thus the destruction of the buildings is built upon it. The direction of flow of surface runoff or storm water discharge should be away from the expansion soil zones. The quicker the water can flow out, the better it is. The integration was carried out between geotechnical distribution maps of the expansion soil and flow of runoff, and the riskiest places had been identified in Tabuk city. The resident neighborhoods built on the expansive shale in the middle of Tabuk city and affected by surface runoff of the tributaries of the basin of Wadi Abu Nishayfah, Na'am and Atanah outlet, represent high-risk zones. These high-risk neighborhoods are Al Qadsiyah, Al Maseif, Arrwdah, Al Nakhil and Al Rajhi. The low-risk zones include the western and the eastern districts; it is non-expansion soil.

This study showed the importance of characterizing geotechnical properties and hydrological elements as part of a comprehensive environmental analysis for future urban planning. Based on the hazard map of the expansive soils of Tabuk city, it found that the western side of the city lying in the upstream of the small basin and the subsurface layers is composed of sandstone. It can suggest that, the western side of Tabuk city is suitable for future urban extension.

\section{Recommendations}

Two major strategies to mitigate hazards resulted from flash floods and runoff on the swelling soil zone (high-risk zone) in Tabuk districts. It is essentially based on prevent or reduce flow of surface runoff and flash floods from the offside Tabuk city and drainage storm water from inside Tabuk districts. The hazards can be mitigated by the following procedures:

1) Construction of water flow retardation structures such as dams, artificial ponds, and orifice divert the course of the wadi etc. in upstream along the main courses of Wadi Abu Nushayfah and Ghudayy, Na'am, Al Baqqar, Dab'an and Atanah and Ghuwaul. This would serve two goals; the first decreasing the flash floods flow to Tabuk city and thus reduces the chance of swelling soils; and the second increasing the contribution to the groundwater aquifer, which depends essentially on rainfall recharge.

2) Nature wadis and artificial open channels that pass into expansion soil areas (hazard zones) within Tabuk city should be refine and lining, to prevent infiltration into the subsurface expansion soil.

3) Benefit from the surface water discharge by matching the paved street layout within the affected districts with the direction of flow, to reduce time of concentration and increase the speed of the discharge. In addition, the direction and slope of the main streets should be in the north direction toward Al Qa'a depression.

4) Construction of storm water network in the hazard zones of Tabuk neighborhoods. 


\section{Acknowledgements}

The Research presented in this paper originated from a Master Degree in Geology from Faculty of Science, Damietta University. The authors are grateful indebted to Prof. Ahmed Basal, Geology Department, Faculty of Science, Damietta University for long-standing collaboration and fruitful scientific discussion. Also, grateful thanks to Dr. Abed El Kareem El Rosttum and Eng. Hikmat El Rosttum, owner of Soil \& Foundation Co. (Safco) and Geotechnical \& Environmental Co. (Geco) Companies, KSA, for offering the laboratory facility to conduct the geotechnical tests of this work.

\section{References}

[1] Seed, H.B., Woodward, R.J. and Lundgren, R. (1962) Prediction of Swelling Potential for Compacted Clays. Journal of Soil Mechanics and Foundation Engineering Division, 88, 53-87.

[2] Li, J., Cameron, D.A. and Ren, G. (2014) Case Study and Back Analysis of a Residential Building Damaged by Expansive Soils. Computers and Geotechnics, 56, 89-99. https://doi.org/10.1016/j.compgeo.2013.11.005

[3] Li, X., Liang, Y., Zhang, P. and Wang, Y. (2010) Research into Treatment Theory and Technique for Expansive Soil Geological Disasters. Memoirs of the Muroran Institute of Technology, 59, 165-171.

[4] Kerrane, J.P. (2011) What Are Expansive Soils. Benson \& Associates PC, Golden.

[5] Rosenbalm, D.C. (2013) Volume Change Behavior of Expansivesoils Due to Wetting and Drying Cycles, Arizona. PhD Thesis, Arizona State University, Phoenix.

[6] Slater, D.E. (1983) Potential Expansive Soils in Arabian Peninsula. American Society for Civil Engineering. Geothermal Engineering, 109, 744-746.

[7] Abduljauwad, S.N. and Ahmed, R. (1990) Expansive Soil in Al-Qatif Area. Arabian Journal of Science and Engineering, 15, 133-144.

[8] Erol, A.O. and Dhowian, A. (1990) Swell Behavior of Arid Climate Shale from Saudi Arabia. Journal of Engineering Geology, 23, 243-254.

https://doi.org/10.1144/GSL.QJEG.1990.023.03.06

[9] Abduljauwad, S.N. (1994) Swelling Behavior of Calcareous Clays from the Eastern Province of Saudi Arabia. Journal of Engineering Geology, 27, 333-351.

https://doi.org/10.1144/GSL.QJEGH.1994.027.P4.05

[10] Al-Sabtan A.A. (2005) Geotechnical Properties of Expansive Clay Shale in Tabuk, Saudi Arabia. Journal of Asian Earth Sciences, 25, 747-757. https://doi.org/10.1016/j.jseaes.2004.07.003

[11] Ruwaih, I.A. (1987) Experiences with Expansive Soils in Saudi Arabia. Proceedings of 6th International Conference on Expansive Soils, New Delhi, 1-4 December 1987, 317-322.

[12] Dhowian, A.W., Erol, A.O. and Youssef, A. (1990). Evaluation of Expansive Soils and Foundation Methodology in the Kingdom of Saudi Arabia. General Directorate Research Grants Programs, King Abdulaziz City for Science and Technology.

[13] Dafalla, M.A. and Al-Shamrani, M.A. (2008) Performance-Based Solutions for Foundations Onexpansive Soils-Al Ghatt Region, Saudi Arabia. International Conference on Geotechnical Engineering, Chiangmai, 10-12 December 2008, 147-156.

[14] Dhowian, A.W. (1984) Characteristics of Expansive Clay-Shale in the Northern Region of Saudi Arabia. Proceedings of the 5 th International Conference on Expansive Soils, Adelaide, 21-23 May 1984, 316-320.

[15] Dafalla M.A. and Al-Shamrani M.A. (2012) Expansive Soil Properties in a Semi-Arid Re- 
gion. Research Journal of Environmental and Earth Sciences, 4, 930-938.

[16] Dafalla, M.A., Al-Shamrani, M.A., Puppala, A. and Ali, H.E. (2010) Use of Rigid Foundation System on Expansive Soils. American Society for Civil Engineers, GSP (Geotechnical Special Publication), 199. https://doi.org/10.1061/41095(365)170

[17] Fredlund, D.G. and Rahardjo, H. (1993) Soil Mechanics for Unsaturated Soils. Wiley, New York. https://doi.org/10.1002/9780470172759

[18] Handy, R.L. (1995) The Day the House Fell: Homeowner Soil Problems from Landslides to Expansive Clays and Wet Basements. ASCE, Reston. https://doi.org/10.1061/9780784401040

[19] Wray, W.K. and Meyer, K.T. (2004) Expansive Clay Soil-A Widespread and Costly GeoHazard. GeoStrata, 5, 24-28.

[20] Mitchell, J.K. and Raad, L. (1973) Control of Volume Changes in Expansive Earth Materials. Proceedings of the Workshop on Expansive Clay and Shales in Highway Design and Construction, 2, 200-219.

[21] Snethen, D.R. and Johnson, L.D. (1980) Evaluation of Soil Suction from Filter Paper. Miscellaneous Paper GL-80-4, US Army Engineer Waterways Experiment Station, Vicksburg.

[22] El Sayed, S.T. and Rabbaa, S.A. (1986) Factors Affecting Behavior of Expansive Soils in the Laboratory and Field-A Review. Geotechnical Engineering, 17, 89-107.

[23] Day, R.W. (1992) Irrigation, Drainage, and Landscaping for Expansive Soil. Journal of Irrigation and Drainage Engineering, 118, 285-290.

http://webistem.com/acoustics2008/acoustics2008/cd1/data/articles/002216.pdf https://doi.org/10.1061/(ASCE)0733-9437(1992)118:2(285)

[24] Federal Emergency Management Agency (FEMA) (1997) Multi Hazard Identification and Risk: Assessment. Expansive Soils.

[25] Abushandi, E. and Alatawi, S. (2015) Dam Site Selection Using Remote Sensing Techniques and Geographical Information System to Control Flood Events in Tabuk City. Hydrology: Current Research, 6, 189.

[26] Abushandi, E. (2016) Flash Flood Simulation for Tabuk City Catchment, Saudi Arabia. Arabian Journal of Geosciences, 9, 188. https://doi.org/10.1007/s12517-015-2192-x

[27] Hussein, M.T. and Zaidi, F.K. (2012) Assessing Hydrological Elements as Key Issue for Urban Development in Arid Regions.

[28] Tabuk, M. (1993) The Town Plans Report. Asia Aaero Survey Company (Personal Communication).

[29] ASTM (1995) Book of Standards, Soil and Rock. Philadelphia.

[30] MOWE (Ministry of Water and Electricity) (2015) Kingdom of Saudi Arabia.

[31] Hyfran, M. (1998) Developed by INRS-Eau with Collaboration of Hydro-Québec Hydraulic Service (Department Hydrology) in the Framework of Hydro-Québec/CRSNG Statistical Hydrology Chair Located at INRS-Eau. http://www.wrpllc.com/books/hyfran.html

[32] US Army Corps of Engineers (USACE) (1998) HEC-1 Flood Hydrograph Package User's Manual, Hydrologic Engineering Center (HEC), Davis.

[33] McCuen, R.H. (2005) Hydrologic Analysis and Design. 3rd Edition, Prentice Hall, Upper Saddle River.

[34] Ally, W.M., Dawdy, D.R. and Schaake, J.C. (1980) Parametric Deterministic Urban Watershed Model. Journal of the Hydraulics Division, 106, 679-690.

[35] US Army Corps of Engineers (USACE) (2000) Hydrologic Modeling System HEC-HMS Technical Reference Manual. Hydrologic Engineering Center, Davis.

[36] Sonbol, M.A., Mtalo, F., El-Bihery, M.A. and Abdel Motaleb, M. (2005) Watershed Model- 
ing of WadiSudr and Wadi Al-Arbain in Sinai, Egypt. International Conference of UNESCO Flanders Fust FriendlNile Project-Towards A Better Cooperation, The 5th Project Management Meeting \& 9 th Steering Committee Meeting, Sharm El-Shiekh, 12-15 November 2005, 1-12.

[37] Soil Conservation Services (SCS) (1985) National Engineering Handbook, Section 4: Hydrology. US Department of Agriculture, Soil Conservation Service, Engineering Division, Washington DC.

[38] Sorman, A.U., Abdulrazzak, M.J. and Elhames, A.S. (1990) Rainfall-Runoff Modeling of Amicrocatchment in the Western Region of Saudi Arabia, Hydrology in Mountainous Regions. I-Hydrological Measurements. IAHS Publ. No. 193.

[39] Osterkamp, W.R., Lane, L.J. and Savard, C.S. (1994) Recharge Estimates Using a Geomorphic Distributed-Parameter Simulation Approach. Amargosa River Basin, 30, 493-507.

[40] Al Dousari, S.A. and Al Ghadban, A.N. (2007) Sustainable Fresh Water Resources Management in Proceedings of World Water and Environmental Resources Congress.

[41] Milewski, A., Sultan M., Yan, E.B., Becker, R., Abdeldayem, A., Soliman F. and Abdel Gelil, K. (2009) A Remote Sensing Solution for Estimating Runoff and Recharge in Arid Environments. Journal of Hydrology, 373, 1-14. https://doi.org/10.1016/j.jhydrol.2009.04.002

[42] Shadeed, S. and Al Masri, M. (2010) Application of GIS-Based SCS-CN Method in West Bank Catchments, Palestine. Water Science and Engineering, 3, 1-13.

[43] Abushandi, E. and Merkel, B. (2011) Modeling Rainfall Runoff Relations Using HEC-HMS and IHACRES for a Single Rain Event in an Arid Region of Jordan. Water Resources Management, 27, 2391-2409. https://doi.org/10.1007/s11269-013-0293-4

[44] Sherif, M.M., Mohamed, M.M., Shetty, A. and Almulla, M. (2011) Rainfall Runoff Modeling of Three Wadis in the Northern Area of UAE. Journal of Hydrologic Engineering, 16, 10-20. https://doi.org/10.1061/(ASCE)HE.1943-5584.0000280

[45] Subyani, A.M. and Al-Ahmadi, F.S. (2011) Rainfall-Runoff Modeling in the Al-Madinah Area of Western Saudi Arabia. Journal of Environmental Hydrology, 19, 1-13.

[46] Ponce, V.M. and Hawkins, R.H. (1996) Runoff Curve Number: Has It Reached Maturity? Journal of Hyrologic Engineering, 1, 9-20. https://doi.org/10.1061/(ASCE)1084-0699(1996)1:1(11)

[47] Janjou, D., Halawani, M.A., Al-Muallem, M.S., Brosse, J.M., Becq-Giraudon, J.F., Dagain, J., Genna, A., Razin, P., Roobol, M.J., Shorbaji, H. and Wyns, R. (1997) Geologic Map of the Tabuk Quadrangle, Sheet 28B, Kingdom of Saudi Arabia (with Text): Saudi Arabian Deputy Ministry for Mineral Resources. Jiddah, Geoscience Map GM-137.

[48] Powers, R.W., Ramirez, L.F., Redomond, C.D. and Elberg, E.L. (1966) Geology of the Arabian Peninsula, Sedimentary Geology of Saudi Arabia. US Geological Survey Professional Paper 560-D, 147.

[49] Parson-Basil Consultants (1967) Agricultural and Water Resources: The Great Nafud Sedimentary Basin. Ministry of Agriculture and Water, Riyadh.

[50] Lloyd, J.W. (1969) The Hydrogeology of the Southern Desert of Jordan. UNDP/FAO Publ. Tech. Rep. 1., Spec. Fund 212, Rome.

[51] Al Watban, N.F. (1976) Groundwater Potentiality of Tabuk and Saq Aquifers in Qasim Region. MSc Thesis, Institute of Applied Geology, Jeddah.

[52] Glintzboeckel, C. (1981) A Tentative Synopsis of the Geology of the Saudi Arabian Sedimentary Basin in Relation to Phosphate Prospecting. Report BRGM-OF-01-23, Jeddah.

[53] Burdon, D.J. (1982) Hydrogeological Conditions in the Middle East. Quarterly Journal of Engineering Geology, 15, 71-82. https://doi.org/10.1144/GSL.QJEG.1982.015.02.01

[54] Lozej, G.P. (1983) Geological and Geochemical Reconnaissance Exploration of the Cover 
Rocks in Northwestern Hijaz. Deputy Ministry for Mineral Resources Open-File Report RF-OF-03-2, Jeddah.

[55] Laboun, A.A. (1986) Stratigraphy and Hydrocarbon Potential of the Paleozoic Succession of Both the Widyan and Tabuk Basins, Arabia. In: Halbouty, M., Ed., Future Petroleum Provinces of the World, American Association of Petroleum Geologists Memoir No. 50, 373-394.

[56] Garfield, L.P. (1984) Mineralisation in Cover Rock Type Shelf-Sediments of the Tethys Margins. Report Riofinex, File RF-DF-01-29, Jeddah.

[57] Williams, P.L., Vaslet, D., Johnson, P.R., Berthiaux, A., Le Start, P. and Fourniguet, J. (1987) Geologic Map of the Jabal Habashi Quadrangle, Sheet 26F, Kingdome of Saudi Arabia (with Text): Saudi Arabian Deputy Ministry for Mineral Resources. Jeddah, Geoscience Map GM-98A. (Scale 1: 250,000)

[58] Dafalla, M.A. and Al-Shamrani, M.A. (2014) Swelling Characteristics of Saudi Tayma Shale and Consequential Impact on Light Structures. Journal of Civil Engineering and Architecture, 8, 613-623.

[59] Van Der Merwe, D.H. (1964) The Prediction of Heave from the Plasticity Index and Percentage Clay Fraction of Soil. South African Institute of Civil Engineers, 6, 103-107.

[60] Sridharan, A. and Prakash, K. (2000) Classification Procedures for Expansive Soils. Geotechnical Engineering, 143, 235-240. https://doi.org/10.1680/geng.2000.143.4.235

[61] Mitchell, J.K. and Soga, K. (2005) Fundamentals of Soil Behavior. 3rd Edition, John Wiley and Sons Inc., New York.

[62] Embaby, A.A., Abu Halawa, A. and Ramadan, M. (2017) An Experimental Study to Mitigate Swelling Pressure of Expansive Tabuk Shale, Saudi Arabia. In Press.

Submit or recommend next manuscript to SCIRP and we will provide best service for you:

Accepting pre-submission inquiries through Email, Facebook, LinkedIn, Twitter, etc.

A wide selection of journals (inclusive of 9 subjects, more than 200 journals)

Providing 24-hour high-quality service

User-friendly online submission system

Fair and swift peer-review system

Efficient typesetting and proofreading procedure

Display of the result of downloads and visits, as well as the number of cited articles

Maximum dissemination of your research work

Submit your manuscript at: http://papersubmission.scirp.org/

Or contact ojmh@scirp.org 